\title{
Surface freshening in the Arctic Ocean's Eurasian Basin: An apparent consequence of recent change in the wind-driven circulation
}

\author{
M.-L. Timmermans, ${ }^{1}$ A. Proshutinsky, ${ }^{2}$ R. A. Krishfield, ${ }^{2}$ D. K. Perovich, ${ }^{3}$ \\ J. A. Richter-Menge, ${ }^{3}$ T. P. Stanton, ${ }^{4}$ and J. M. Toole ${ }^{2}$ \\ Received 19 January 2011; revised 30 March 2011; accepted 28 April 2011; published 23 July 2011.
}

[1] Data collected by an autonomous ice-based observatory that drifted into the Eurasian Basin between April and November 2010 indicate that the upper ocean was appreciably fresher than in 2007 and 2008. Sea ice and snowmelt over the course of the $2010 \mathrm{drift}$ amounted to an input of less than $0.5 \mathrm{~m}$ of liquid freshwater to the ocean (comparable to the freshening by melting estimated for those previous years), while the observed change in upper-ocean salinity over the melt period implies a freshwater gain of about $0.7 \mathrm{~m}$. Results of a wind-driven ocean model corroborate the observations of freshening and suggest that unusually fresh surface waters observed in parts of the Eurasian Basin in 2010 may have been due to the spreading of anomalously fresh water previously residing in the Beaufort Gyre. This flux is likely associated with a 2009 shift in the large-scale atmospheric circulation to a significant reduction in strength of the anticyclonic Beaufort Gyre and the Transpolar Drift Stream.

Citation: Timmermans, M.-L., A. Proshutinsky, R. A. Krishfield, D. K. Perovich, J. A. Richter-Menge, T. P. Stanton, and J. M. Toole (2011), Surface freshening in the Arctic Ocean's Eurasian Basin: An apparent consequence of recent change in the wind-driven circulation, J. Geophys. Res., 116, C00D03, doi:10.1029/2011JC006975.

\section{Introduction}

[2] Fresh water maintains the strong near-surface Arctic Ocean stratification that inhibits transfer of deep ocean heat to the surface, and consequently has a major impact on sea ice cover, and the entire Arctic climate system. The spatial distribution of liquid fresh water is controlled by: sea ice growth and decay; advection of fresh river water and relatively low salinity Pacific water from the Arctic marginal seas; precipitation; and wind forcing, which affects sea ice drift and water-mass pathways and modulates the depth of the halocline. These processes contribute to the time-varying liquid freshwater content to varying degrees in the different Arctic Ocean regions and over seasonal to decadal time scales [e.g., Steele and Ermold, 2004; Serreze et al., 2006; Polyakov et al., 2008; Newton et al., 2008; Dmitrenko et al., 2008; Rabe et al., 2010]. In this paper, we examine recently observed substantial changes in the Eurasian Basin mixed-layer salinity

\footnotetext{
${ }^{1}$ Department of Geology and Geophysics, Yale University, New Haven, Connecticut, USA.

${ }^{2}$ Department of Physical Oceanography, Woods Hole Oceanographic Institution, Woods Hole, Massachusetts, USA.

${ }^{3}$ Cold Regions Research and Engineering Laboratory, Hanover, New Hampshire, USA.

${ }^{4}$ Department of Oceanography, Naval Postgraduate School, Monterey, California, USA.

Copyright 2011 by the American Geophysical Union. 0148-0227/11/2011JC006975
}

in the context of seasonal processes and the large-scale atmospheric circulation. The mechanisms of the coupled Arctic ocean-sea ice-atmosphere system examined here offer a foundation for model validation and improvement, contributing to the Arctic Ocean Model Intercomparison Project (AOMIP) community.

[3] Changes in the freshwater distribution of the upper ocean have been shown to be linked to major shifts in Arctic wind forcing regimes that occur on time scales of several years to decades [e.g., Morison et al., 1998; Steele and Boyd, 1998; Anderson et al., 2004; Morison et al., 2006; Alkire et al., 2007; Newton et al., 2008]. Upper-ocean salinity changes are particularly large in the central Arctic Ocean in the vicinity of the front between less saline water masses of Pacific character and more saline water masses of Atlantic character [e.g., Morison et al., 1998; McLaughlin et al., 2004]. Rapid changes (on interannual, and possibly seasonal, time scales) in upper-ocean freshwater content in parts of the central Arctic Ocean take place as a result of shifts in this frontal zone. For example, Morison et al. [1998] showed that in the 1990s the front shifted from roughly over the Lomonosov Ridge (based on pre-1990s climatology) to roughly over the Alpha and Mendeleyev Ridges, and that this change in the ice and upper-ocean circulation could be attributed to a shift in atmospheric circulation. At the same time, the cold Arctic halocline disappeared from the Eurasian Basin, while mixed layers became more saline there [Steele and Boyd, 1998]. In the 2000s, upper-ocean salinity and temperature in the central Arctic Ocean returned to approximately pre-1990s conditions [Morison et al., 2006] and 
the Eurasian Basin saw a partial return of the cold halocline [Boyd et al., 2002].

[4] Similarly, the atmospheric circulation effectively regulates the strength and position of the Beaufort Gyre circulation system, centered in the Canada Basin. Owing to prevailing anticyclonic (clockwise) winds generated by the Arctic high, the Beaufort Gyre accumulates fresh water from sea ice melt, Pacific Water inflows through Bering Strait, river runoff and atmospheric precipitation in the upper ocean primarily by Ekman convergence [e.g., Proshutinsky et al., 2002]. There is a direct correlation between the size and intensity of the Arctic high, position of the frontal zone discussed above, freshwater content in the Beaufort Gyre region and changes in upper-ocean salinity in the Eurasian basin. The large-scale atmospheric winds redistribute water masses such that an increase of fresh water in the Beaufort Gyre results in a deficit of fresh water (i.e., an upper-ocean salinity increase) in the Eurasian sector of the Arctic Ocean and vice versa. Aagaard and Carmack [1989] showed that a deeper halocline and fresher surface waters in the Canadian Basin result in about 4 times more liquid fresh water (relative to a salinity of 34.8) than in the Eurasian Basin. Recent years have seen an unprecedented increase of fresh water accumulated in the Beaufort Gyre: specifically, between 2003 and 2009, the freshwater content of the Beaufort Gyre increased by more than 30\% [Proshutinsky et al., 2009]. Locally, McPhee et al. [2009] show that in parts of the southeast Canada Basin, freshwater content in 2008 was as much as $60 \%$ above the climatological values. Note that McPhee et al. [2009] found a significant reduction in freshwater content in the Makarov and Amundsen basins.

[5] A conceptual model put forward by Proshutinsky et al. [2002] asserts that the Beaufort Gyre accumulates a considerable volume of fresh water under large-scale anticyclonic wind forcing (high surface atmospheric pressure), and releases this fresh water when the forcing weakens or changes sense to cyclonic. In this scenario, anticyclonic winds tend to accumulate fresh water in the Beaufort Gyre by Ekman convergence while the cyclonic circulation regime is associated with Ekman divergence and a reduction of fresh water in the Gyre [see also Hunkins and Whitehead, 1992]. In addition to this dynamic forcing, thermodynamic forcing (sea ice growth and decay) also regulates Beaufort Gyre liquid fresh water. Proshutinsky et al. [2009] showed that the mean seasonal cycle of ocean fresh water in the Beaufort Gyre has two peaks: one in summer when the sea ice thickness reaches its minimum (maximum ice melt), and the other in late fall-early winter when the wind stress curl is strongest (maximum Ekman pumping) while the salt input from growing sea ice has not yet reached its maximum. Between 1997 through 2008, the Arctic was characterized by a strong anticyclonic circulation. The unusually long 12 year anticyclonic conditions were likely a major factor in the substantial increase in Beaufort Gyre fresh water over this time [Proshutinsky et al., 2009; McPhee et al., 2009].

[6] Freshwater content variability is further impacted by changes in freshwater sources [e.g., Peterson et al., 2002]. For example, Eurasian river runoff to the Arctic was 25\% larger in 2007 than the mean river influx between 1936 and 2006 [Shiklomanov and Lammers, 2009]; these sizable variations are superimposed on local freshwater changes arising from changes in the large-scale circulation. At the same time, river discharge is influenced by the large-scale atmospheric circulation. Proshutinsky et al. [2000] show that during anticyclonic wind regimes, atmospheric cyclone trajectories are shifted toward Siberia, bringing increased precipitation that feeds Siberian rivers. This is in contrast to cyclonic wind regimes when cyclones propagate preferentially to the Central Arctic, and Siberian river discharge decreases. The most intense annually averaged anticyclonic circulation in the last 60 years was seen in 2007 [Proshutinsky and Johnson, 2010], consistent with the observed maximum river discharge [Shiklomanov, 2010; Shiklomanov and Lammers, 2009].

[7] In this study, we examine the consequences of a significant change in 2009 in the wind-driven circulation (on a background of seasonal melt) to the surface ocean freshwater content in the Eurasian Basin. We assess the evolution and spatial distribution of fresh water in the ocean mixed layer by analyzing ocean and sea ice measurements from an ice-based observatory (IBO) that drifted in the Eurasian Basin in 2010, together with hydrographic data collected in the same region in previous years. We interpret our observational results in the context of the large-scale circulation by employing a windforced Arctic Ocean model with frictional coupling between the ocean and sea ice [see Proshutinsky and Johnson, 1997]. The model is used to examine the transport of fresh surface waters from the Beaufort Gyre and Siberian shelf regions to the Eurasian Basin and Fram Strait, and to provide support to our hypothesis on the origin of observed fresh water in the Eurasian Basin. In section 2, we investigate seasonal melt and the freshwater content of surface waters measured by an IBO that was deployed on a $1.7 \mathrm{~m}$ thick ice floe in the Transpolar Drift on 19 April 2010 at $88^{\circ} 39.4^{\prime} \mathrm{N}, 145^{\circ} 35.7^{\prime} \mathrm{E}$ in conjunction with the North Pole Environmental Observatory (NPEO) program. The IBO included a Woods Hole Oceanographic Institution ice-tethered profiler (ITP), a U.S. Army Cold Regions Research and Engineering Laboratory ice mass balance buoy (IMB), a Naval Postgraduate School Arctic Ocean flux buoy (AOFB), and a National Oceanic and Atmospheric Administration (NOAA)-Pacific Marine Environmental Laboratory (PMEL) Web camera. The combined ITP and IMB instrumentation allows us to estimate the surface ocean freshening due to ice and snowmelt over the course of the IBO drift (Figure 1) and to relate this to concurrent upper-ocean temperature and salinity measurements. In addition to estimating bounds on freshening due to local melt, we compare data from previous years to show that the entire IBO drift region was significantly fresher in 2010 compared to 2007 and 2008 even though seasonal melt was comparable in all 3 years. In section 3, we employ the two-dimensional model to explore the wind-driven sea ice and upper-ocean Arctic circulation in the context of the observations. In section 4, results are summarized and discussed in perspective with past upper-ocean circulation changes in the region.

\section{Upper-Ocean Freshening}

\subsection{IBO Measurements}

[8] The Ice-Mass Balance Buoy consists of a thermistor string extending from the surface through the snow and ice into the upper ocean (typically between 200 and $380 \mathrm{~cm}$ below the top surface of the ice), acoustic sounders above the ice-snow surface and below the ice bottom, GPS, barometer, air temperature sensor, and an Iridium transmitter for data 


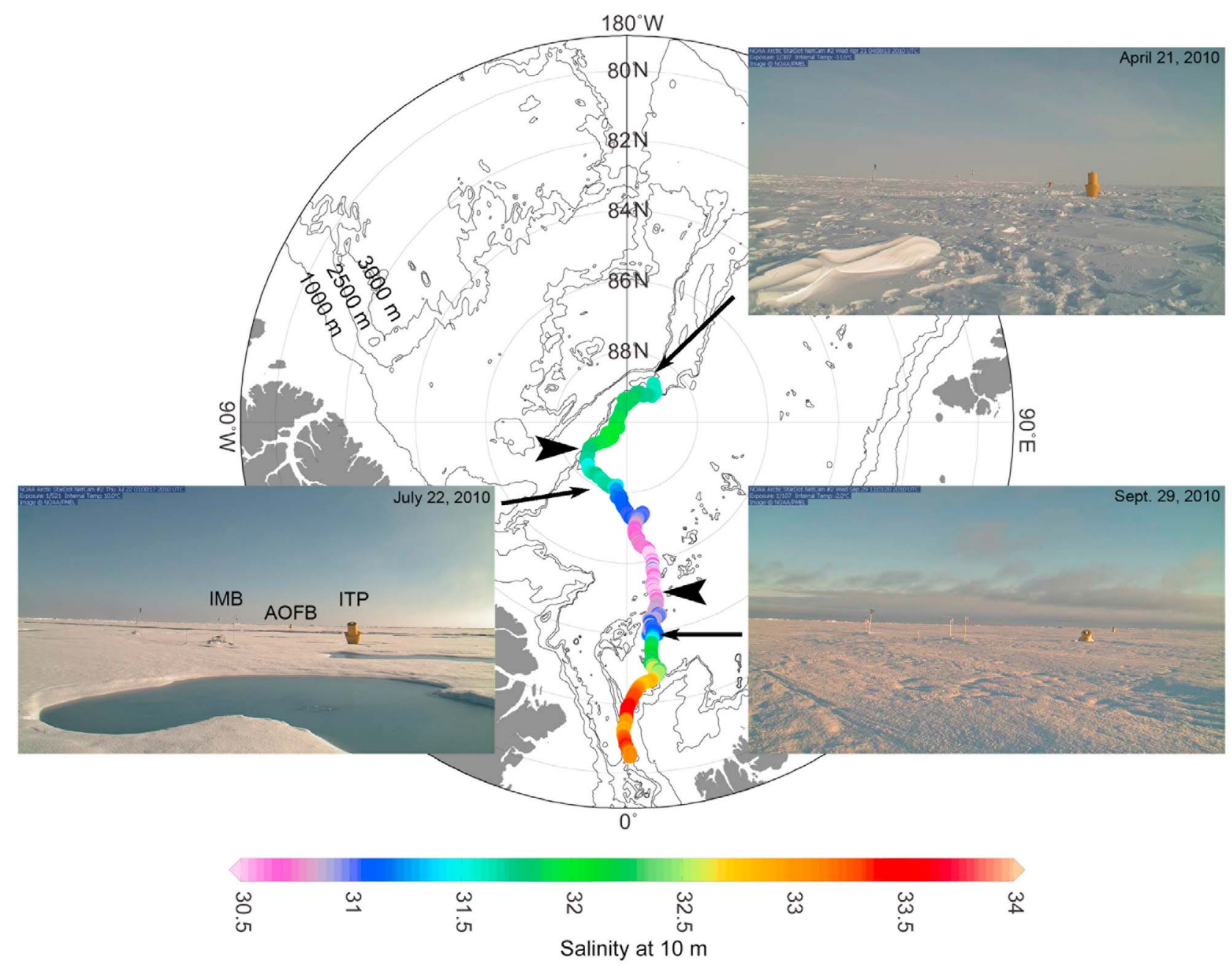

Figure 1. Drift track of the ice-based observatory (IBO) between 19 April 2010 and 10 November 2010, indicating ice-tethered profiler (ITP) salinity at $10 \mathrm{~m}$. The 1000, 2500, and $3000 \mathrm{~m}$ isobaths have been plotted using the International Bathymetric Chart of the Arctic Ocean (IBCAO) grid. Images are from the NOAA Pacific Marine Environmental Laboratory (PMEL) Web camera installed on the same floe. Black pointers indicate the IBO location at the start and end of the melt period.

recovery [Richter-Menge et al., 2006] (http://imb.crrel.usace. army.mil/). The ITP system consists of a surface buoy deployed in the ice floe, and an automated profiling CTD instrument that is mounted to a tether that extends to about $750 \mathrm{~m}$ below [Krishfield et al., 2008] (http://www.whoi.edu/ page.do?pid=20756). The profiling CTD cycles vertically along the tether from about $7 \mathrm{~m}$ depth to about $750 \mathrm{~m}$; the systems examined here returned four one-way profiles of temperature and salinity (at about $25 \mathrm{~cm}$ vertical resolution) per day via Iridium satellite (data are available on the ITP Web site at http://www.whoi.edu/itp/data/). The Autonomous Ocean Flux Buoy consists of a surface buoy that sits on the ice and an instrument frame suspended into the upper ocean. The instrument frame includes an acoustic travel time current meter (Falmouth Scientific Inc., FSI) located nominally $4 \mathrm{~m}$ below the ice that measures three component velocities with $\mathrm{mm} \mathrm{s}^{-1}$ noise levels. A submillidegree resolution thermistor string with sensors spaced $0.4 \mathrm{~m}$ apart extended up from the velocity sensor into the ice allowing the thermal structure within the upper part of the ocean mixed layer to be characterized. AOFB data are transmitted daily by Iridium satellite and near realtime data are available on the flux buoy Web site (http://www.oc.nps.edu/stanton/fluxbuoy/).

[9] IMB 2010A and ITP 38 were deployed about $10 \mathrm{~m}$ apart (this distance did not change over the 7 month drift), with AOFB 20 deployed about $60 \mathrm{~m}$ from the other buoys. Around the end of May, Web camera images show that a lead opened between the AOFB and the other instruments on the floe. There was some relative motion between the AOFB and other instruments until around the end of August, but all instruments remained within the field of view of the NOAAPMEL Web camera. Time series of floe speed, internal ice temperature, and upper-ocean temperature and salinity from the IMB and ITP span the 2010 melt season, defined by the initiation and end of ice base ablation measured by the IMB as between 25 June and 7 September 2010 (Figure 2). Note that defining the beginning and end of melt is somewhat subjective. For example, major bottom melt started about 


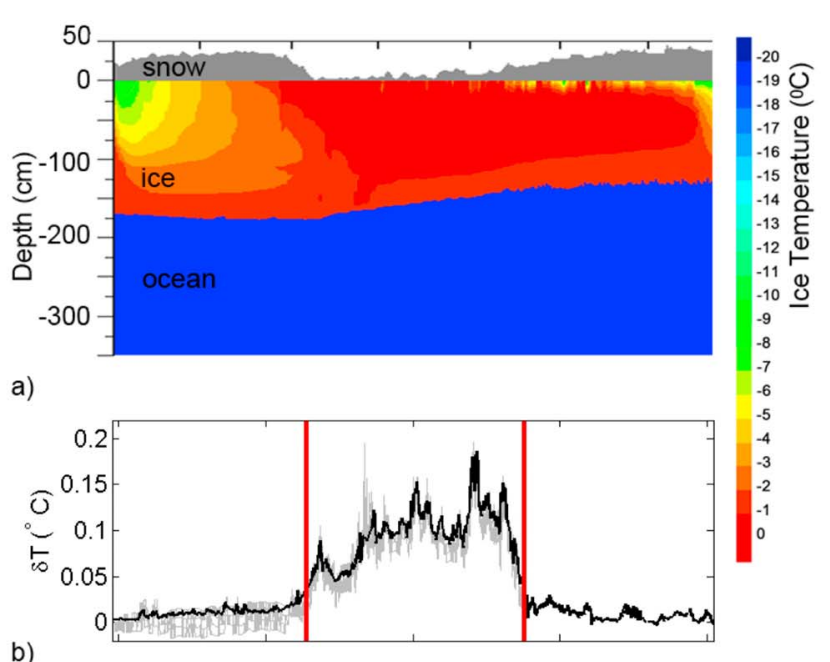

b)

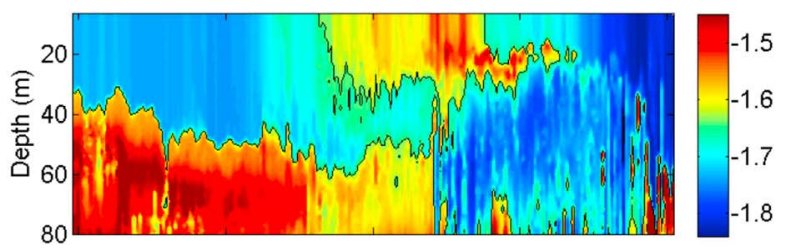

c)

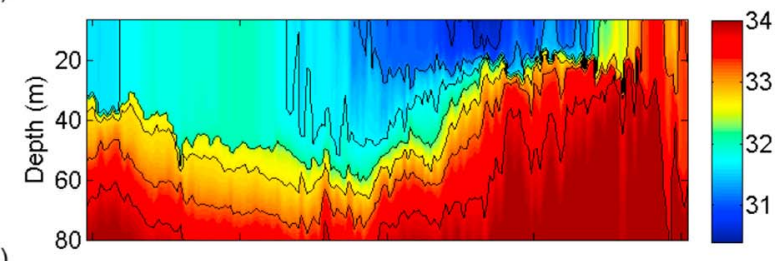

d)

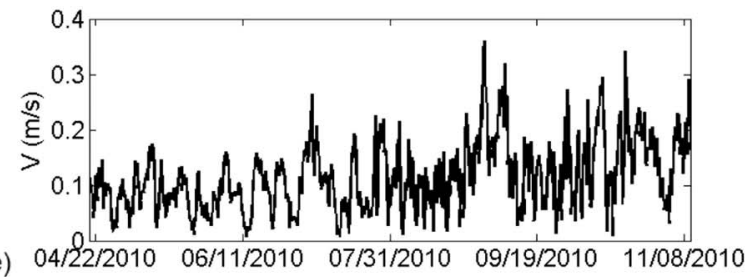

Figure 2. (a) Ice mass balance buoy (IMB) snow and ice thickness and internal ice temperature. (b) ITP temperature difference from freezing at $7 \mathrm{~m}$ with IMB water-column temperature difference from freezing from the 19 thermistors between 200 and $380 \mathrm{~cm}$ depth below the top surface of the ice. Vertical red lines mark the start and end of the melt period, which we define by initiation and end of bottom ablation measured by the IMB. Depth-time sections of (c) ITP potential temperature and (d) salinity. (e) Drift speed $V$ of the ice floe computed from ITP GPS positions.

29 June and there was still some minor, much slower, bottom melt after 7 September.

[10] ITP calibration procedures are described by Johnson et al. [2007] and R. Krishfield et al. (unpublished manuscript, 2008) (see http://www.whoi.edu/page.do?pid=23096). Predeployment laboratory-derived calibrations were adopted for all temperature and pressure data (postdeployment laboratory calibrations of two recovered ITPs documented tem- perature and pressure offsets after $2-3$ years of $0.001^{\circ} \mathrm{C}$ to $0.002^{\circ} \mathrm{C}$ and around $1 \mathrm{dbar}$, respectively). These are taken as the uncertainties of the final ITP temperature and pressure data. Adjustments to the laboratory conductivity calibrations were derived and applied as detailed by Krishfield et al. (unpublished manuscript, 2008) to achieve consistency with recently acquired ship-based salinity estimates for the region. The resultant ITP salinity data have an uncertainty (relative to the ship data) of 0.005 or less. IMB thermistors were calibrated by applying an offset (specified by setting the initial thermistor value equal to freezing temperature based on the $7 \mathrm{~m}$ salinity of the ITP) to each thermistor series. The magnitude of the offset was no more than $0.06^{\circ} \mathrm{C}$. This assumes a homogeneous mixed layer at freezing temperature on 20 April above the top depth sampled by the ITP. Freezing temperature was calculated using the ITP salinity time series at $7 \mathrm{~m}$. IMB temperature measurements (between 200 and $380 \mathrm{~cm}$ below the top surface of the ice) do not deviate from ITP temperatures at $7 \mathrm{~m}$ depth (the top depth sampled by the ITP) over the duration of the drift. While this might be expected since ITP vertical profiles indicate mixed-layer depths were never shallower than about $12 \mathrm{~m}$ over the course of the IBO drift, it allows us to rule out that water properties immediately below the sea ice were different than those sampled by the ITP at $7 \mathrm{~m}$.

\subsection{Summer Melt}

[11] Over the melt period, IMB 2010A documented a net sea ice bottom ablation of $0.40 \mathrm{~m}$, and negligible surface ice melt. Total snowmelt was $0.35 \mathrm{~m}$. The measured bottom ablation implies the total heat input to the ice cover during the melt period was about $119 \mathrm{MJ} \mathrm{m}^{-2}$ (given the latent heat of fusion $3.34 \times 10^{5} \mathrm{~J} \mathrm{~kg}^{-1}$, and assuming no increase in heat content of the ice base; Figure 2), equivalent to an average net ocean-toice heat flux over the melt period of about $18 \mathrm{~W} \mathrm{~m}^{-2}$.

[12] The ocean-to-ice heat flux can be estimated by [McPhee, 1992]

$$
F_{H}=\rho c_{p} c_{H} u_{* 0} \delta T,
$$

where $c_{p}=3980 \mathrm{~J} \mathrm{~kg}^{-1}$ is the specific heat of seawater, $c_{H}=$ 0.0057 is a heat transfer coefficient [see McPhee et al., 2003], $\delta T$ is the difference between mixed-layer temperature and freezing temperature (a function of mixed-layer salinity), and $u_{* 0}$ is the interface friction speed. The velocity $\mathbf{u}_{*_{0}}$ may be estimated from ice-drift velocity $(\mathbf{V}$, where, as is common, we assume the geostrophic flow is much smaller than the winddriven ice-drift velocity) using a Rossby similarity relationship (see McPhee [2008] for a full discussion):

$$
\frac{\kappa \mathbf{V}}{\mathbf{u}_{* 0}}=\log \frac{\left|u_{* 0}\right|}{f z_{0}}-A-i B,
$$

where $\mathbf{u}_{* 0}$ and $\mathbf{V}$ are horizontal vectors expressed as complex numbers, $\kappa=0.4$ is von Karman's constant, and $f$ is the Coriolis parameter with constants $A=2.12, B=1.91$. One source of error is associated with estimating the undersurface roughness $z_{0}$ [see Wettlaufer, 1991]. Following McPhee et al. [2003], we take $z_{0}=0.01 \mathrm{~m}$ for consistency between our estimates and heat fluxes inferred from an IBO deployed in April 2002 as part of the NPEO [McPhee et al., 2003; see also 

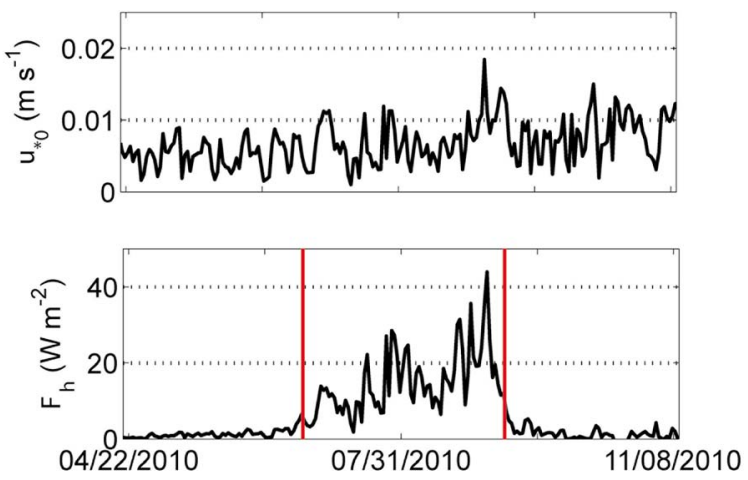

Figure 3. (top) Interfacial friction speed from ice velocity and equation (2). (bottom) Estimated basal heat flux derived from equation (1). Vertical red lines mark the start and end of the melt period.

Krishfield and Perovich, 2005]. Also following McPhee et al. [2003], we remove tidal and inertial components from $\mathbf{V}$ before applying (2) under the assumption that the inertial component of shear at the ice-ocean interface can be neglected and the ice and upper ocean react in the same way to tidal forcing (further discussion is given by McPhee [2008]). Employing (1) and (2) yields a mean ocean-to-ice heat flux over the melt period of about $15 \mathrm{~W} \mathrm{~m}^{-2}$ (Figure 3), roughly consistent with the observed sea ice bottom melt. Note that in this case the heat that causes basal ice melt derives entirely from surface-ocean warming by incoming solar radiation through open leads, rather than entrainment of heat from warmer water below the mixed layer; during the melt period the warm surface water is insulated by a cool halocline from the underlying warm water (Figure 2). The mean heat flux is not significantly different from heat flux estimates over the same period from the 2002 NPEO IBO analyzed by McPhee et al. [2003, Figure 3].

[13] For comparison, interfacial-friction velocity was obtained directly by the correlation of the fluctuating horizontal and vertical components of velocity at $4 \mathrm{~m}$ measured by AOFB 20 (Figure 4). Variable $u_{* 0}$ measured from $40 \mathrm{~min}$ ensembles of Reynolds stresses was typically only about $2 / 3$ the magnitude of $u_{* 0}$ derived using equation (2), suggesting that the value of $z_{0}$ used to characterize undersurface roughness is too large for this floe, at least in the vicinity of the AOFB. Note that the two $u_{* 0}$ time series are only weakly correlated, with a correlation coefficient of 0.3 , over the deployment. Over the melt period, the average heat flux calculated from equation (1) using the direct $u_{*}$ and the temperature series from the thermistor closest to the ice is about $10 \mathrm{~W} \mathrm{~m}^{-2}$; this heat flux would yield only about one-half of the observed bottom ablation $(0.2 \mathrm{~m}$ compared to $0.4 \mathrm{~m}$ ). Estimates of $u_{* 0}$ based on the Rossby similarity drag law depend on the choice of a roughness scale $z_{0}$, while the direct measurements of $u_{* 0}$ at $4 \mathrm{~m}$ depth are sensitive to local under-ice morphology [see, e.g., Shaw et al., 2008]. The Web camera images show substantial heterogeneity of the ice surface over the course of the melt season that is likely replicated on the bottom surface of the ice. Further, the AOFB is positioned on the other side of a working lead for most of the melt period. We will show that even taking melt measured by the IMB as an upper bound for the region, the measured freshening (compared to previous years) is far too large to be attributed to melt.

[14] Given the densities of ice $\rho_{i} \approx 900 \mathrm{~kg} \mathrm{~m}^{-3}$ and snow $\rho_{s} \approx 330 \mathrm{~kg} \mathrm{~m}^{-3}$, the total melt is equivalent to a mixed-layer input of about $0.47 \mathrm{~m}$ of fresh water. This is an upper bound, assuming all the snowmelt equivalent fresh water $(0.10 \mathrm{~m})$ is input to the surface ocean (i.e., we do not account for snow sublimation [e.g., Déry and Yau, 2002] or collection of melt in melt ponds, both of which would reduce the equivalent freshwater input). For comparison, freshwater content of the surface mixed layer over the course of the IBO drift (relative to freshwater content on 25 June 2010 at the onset of the melt period) can be calculated assuming the mixed-layer salinity remains uniform from above the top depth $(7 \mathrm{~m})$ sampled by the ITP to the ice-ocean interface. If mixed-layer salinity on 25 June is $S_{0}$, relative fresh water content (in meters) for a mixed layer of salinity $S$ and depth $D$ is $\left(S_{0}-S\right) D / S_{0}$. Mixedlayer depth $D$ is calculated to be where the potential density relative to 0 dbar first exceeds the shallowest sampled density by $0.01 \mathrm{~kg} \mathrm{~m}^{-3}$ [see Toole et al., 2010]. We estimate a change in freshwater content of the ocean mixed layer of about $0.7 \mathrm{~m}$ between 25 June and 7 September, about $30 \%$ more than can be attributed to melt (Figure 5). In general over the melt
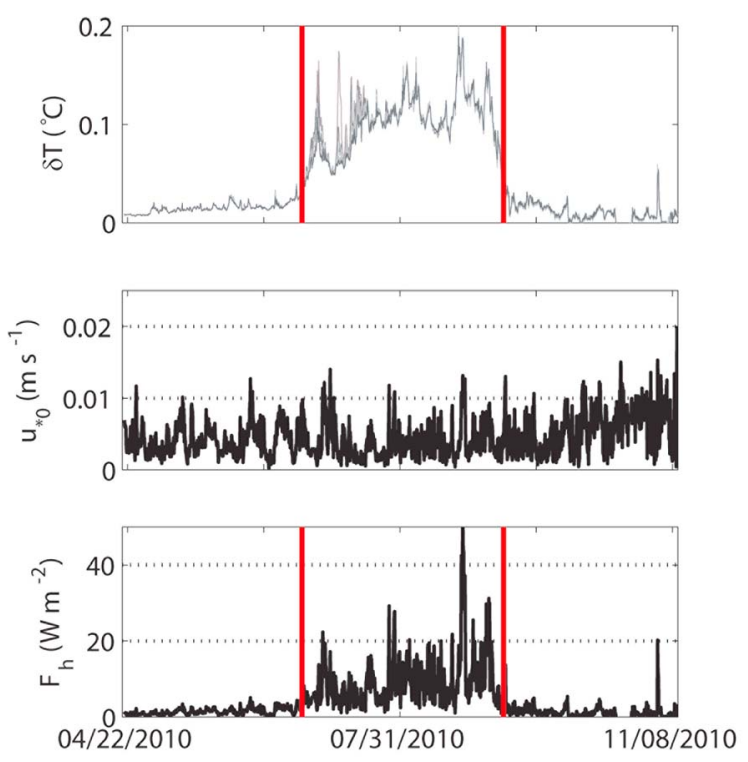

Figure 4. (top) Arctic Ocean flux buoy (AOFB) temperature difference from freezing at eight levels (separated by $0.4 \mathrm{~m}$ ) above approximately $4 \mathrm{~m}$ below the top surface of the ice. The top thermistor (warmest) indicates that the mixed layer was largely isothermal during the summer, with warmer surface waters around the beginning of July. (middle) Eddycorrelation-based interfacial-friction speed measured at $4 \mathrm{~m}$ below the ice (measured by AOFB 20). Note that the $u_{* 0}$ levels are lower than estimates in Figure 3, implying that the ice was smoother at the IBO site than inferred by the $z_{0}=$ $0.01 \mathrm{~m}$ roughness value used in equation (2). (bottom) Estimated basal heat flux derived from the highest thermistor value (Figure 4, top), $u_{* 0}$ (Figure 4, middle), and equation (1). Vertical red lines mark the start and end of the melt period. 


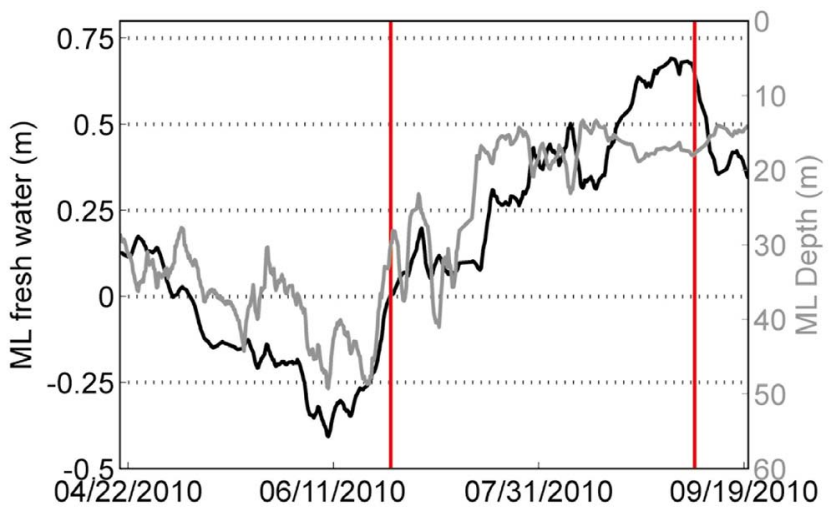

Figure 5. Change in freshwater content of the surface mixed layer over the course of the IBO drift (calculated relative to freshwater content on 25 June 2010 at the onset of the melt season) (solid curve). Mixed-layer depth defined as that point where the potential density relative to $0 \mathrm{dbar}$ first exceeded the shallowest sampled density by $0.01 \mathrm{~kg} \mathrm{~m}^{-3}$ (shaded curve). The mixed-layer salinity was taken as the mean over the mixed layer and was assumed to remain uniform from above the top depth $(7 \mathrm{~m})$ sampled by the ITP. Vertical red lines mark the start and end of the melt period.

season, the relative freshwater content increases as the mixed layer thins; note the significantly larger impact of the change in salinity (compared to changes in mixed-layer depth) on freshwater content for the ranges of change observed in mixed-layer depth and salinity in this case. An alternative approach to calculating upper-ocean freshwater content is to integrate the salinity anomaly between a fixed depth and the ice-ocean interface. This approach, with a fixed depth of $25 \mathrm{~m}$ (the mean mixed-layer depth over the melt period), yields a similar freshwater content increase (about $0.7 \mathrm{~m}$ over the melt period). While it would appear that there is excess fresh water in the region that cannot be attributed entirely to seasonal melt, the possibility exists that spatial gradients sampled by a drifting ITP could be interpreted as temporal changes. However, as will be discussed in the next section, observations indicate that the entire region was significantly fresher in 2010 compared to 2007 and 2008 even though seasonal melt was comparable in all 3 years.

\subsection{Interannual Variability}

[15] Over the course of the 2010 melt season the IBO drifted about $500 \mathrm{~km}$ south, beginning in late June when it turned off the Lomononosov Ridge axis around $88^{\circ} \mathrm{N}$. The fresher mixed-layer recorded during this drift is in contrast to surface salinity distributions of preceding years (Figure 6). ITP drifts in 2007 (ITP 7) and 2008 (ITP 19) indicated saltier mixed layers with correspondingly lower freshwater content in the vicinity of the 2010 IBO drift track, even though freshwater input due to melt in 2007 and 2008 was roughly comparable to that in 2010. An IMB was part of a manned station during the drift of the schooner Tara from the North Pole region toward Fram Strait over the 2007 melt period [see Nicolaus et al., 2010]. The IMB indicated an ice thickness decrease of $0.63 \mathrm{~m}(0.53 \mathrm{~m}$ surface melt and $0.10 \mathrm{~m}$ bottom $)$ and total snowmelt of $0.18 \mathrm{~m}$ between June and August 2007 . The following year, an IMB (2008E) deployed with ITP 19 recorded a total ice thickness decrease of about $0.60 \mathrm{~m}$ and total snowmelt of about $0.20 \mathrm{~m}$ between June and August 2008. This yields surface-ocean freshwater equivalent increases from melt of about $0.6 \mathrm{~m}$ over the 2007 and 2008 melt periods, comparable to freshwater input from melt inferred from the IMB drifting in the same region in 2010. There was not an ITP deployment in the North Pole to Fram Strait region in 2009, but measurements from a Naval Postgraduate School Arctic Ocean Flux Buoy (AOFB), which had a conductivity sensor at nominally 4 meters below the sea ice base, indicate fresher mixed layers (comparable to 2010) measured by the AOFB until around the beginning of June when it crossed $88^{\circ} \mathrm{N}$ (Figure $6 \mathrm{c}$ ). This suggests that the region along the prime meridian was in transition in 2009; saltier mixed layers, similar to conditions in 2007-2008, were recorded over the southern portion of the 2009 AOFB drift. IMB 2009A deployed on the same floe with the AOFB transmitted data only until 5 August 2009. Over this time, it recorded a total snowmelt of $0.48 \mathrm{~m}$ and ice melt of about $0.10 \mathrm{~m}$, equivalent to a freshwater input of about $0.23 \mathrm{~m}$, although with about one month remaining in the melt season.

[16] By the time the 2010 IBO neared the vicinity of Fram Strait (around $81^{\circ} \mathrm{N}$ at the beginning of November 2010), mixed-layer salinities were comparable to those measured by ITP 7 at the start of October 2007 in the same location (drift tracks of the two ITPs crossed at the prime meridian near $81^{\circ} \mathrm{N}$ ). It may be that the freshening was confined to the western part of Fram Strait because the anomalously fresh water exited as a boundary current along the East Greenland coast.

[17] The Environmental Working Group (EWG) Joint U.S.Russian Atlas of the Arctic Ocean summer (July, August, September) climatology for the decades of 1950 to 1980 indicates a significantly fresher surface ocean in 2010 along the IBO drift track south of $88^{\circ} \mathrm{N}$ (Figure 7). However, such comparisons must be made with caution given the limited numbers of historical stations in the region (in this sector of the Arctic, north of $84^{\circ} \mathrm{N}$, the total number of stations used in the EWG interpolation was less than 20 stations per decade between the 1950s and 1980s) and the strong seasonal, interannual and spatial variability of mixed-layer salinity. Two other ITPs (ITP 29 and ITP 37) operated in different parts of the basin over the same time as the 2010 IBO and provide an indication of the strong lateral surface-ocean salinity gradients in the region and the distinct distribution of surface fresh water (Figure 6d). These measurements suggest that the observed 2010 freshening was most pronounced in the western Eurasian Basin. Comparison to climatology shows a consistently fresher surface ocean along the drift track of ITP 29 with no consistent difference along the track of ITP 37 (Figure 7). On the other hand, comparison of measurements from ITP 7 (2007) and ITP 19 (2008) (Figures 6a and 6b) to climatology indicates saltier surface salinities over the entire summer southward drift tracks in the Eurasian Basin in those years (Figure 7). Note that this is consistent with McPhee et al. [2009] who showed a negative anomaly in freshwater content between climatology and 2008 on the Eurasian side of the Lomonosov Ridge. McPhee et al. [2009] showed that compared with winter climatological values in the same areas, 2008 freshwater volume in the Eurasian area decreased by about $26 \%$. We will discuss in section 4 how related transitions 

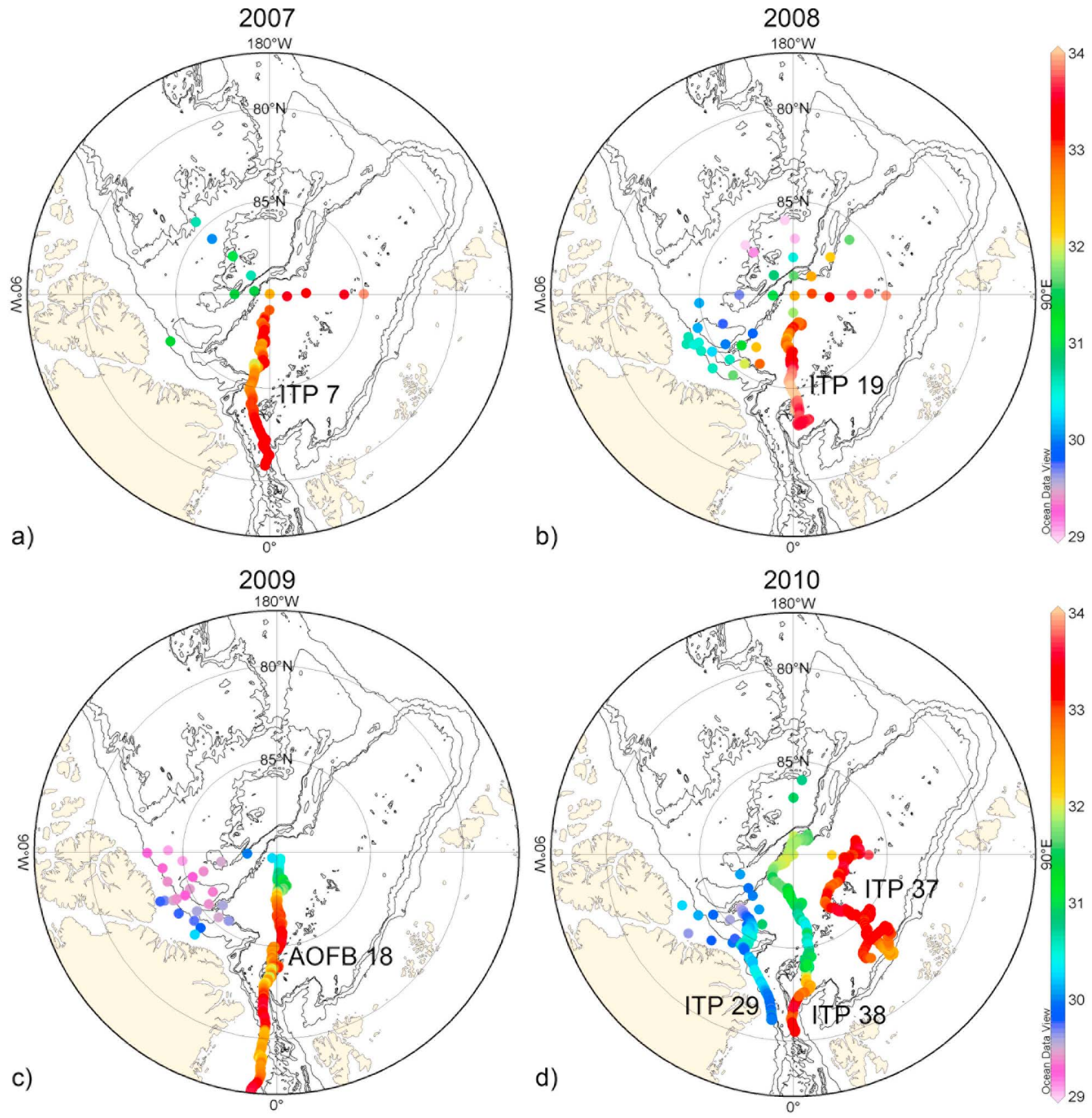

Figure 6. Map of salinity at $10 \mathrm{~m}$ from North Pole Environmental Observatory and Switchyard conductivity-temperature-depth stations and ITP profiles between 1 April and 10 November for the years shown. The 1000, 2500, and $3000 \mathrm{~m}$ isobaths are shown. The last profile in the drift of ITP 29 (2010) was taken on 15 September 2010. In 2009, measurements from a Naval Postgraduate School AOFB are also shown (at a depth of nominally $4 \mathrm{~m}$ below the sea ice base).

in upper-ocean properties in the region have been observed in other years.

[18] CTD data taken between 2007 and 2010 in April-May in the vicinity of the North Pole and in the Switchyard region (between Ellesmere Island-Northern Greenland and the North Pole) also show the appreciably fresher surface waters in 2010 (Figure 6). Profiles from the NPEO aircraft surveys (on the Eurasian Basin side of the Lomonosov Ridge) and Switchyard surveys indicate mixed layers in the region becoming progressively fresher between 2007 and 2009. In 2010, parts of the Switchyard region appear to return to slightly saltier values or stay the same as 2009, although the entire region remains fresher than in 2007 and 2008.

[19] A detailed analysis of changes below the mixed layer, in the halocline and deeper, is beyond the scope of this study. However, we point out that there were significant changes in 

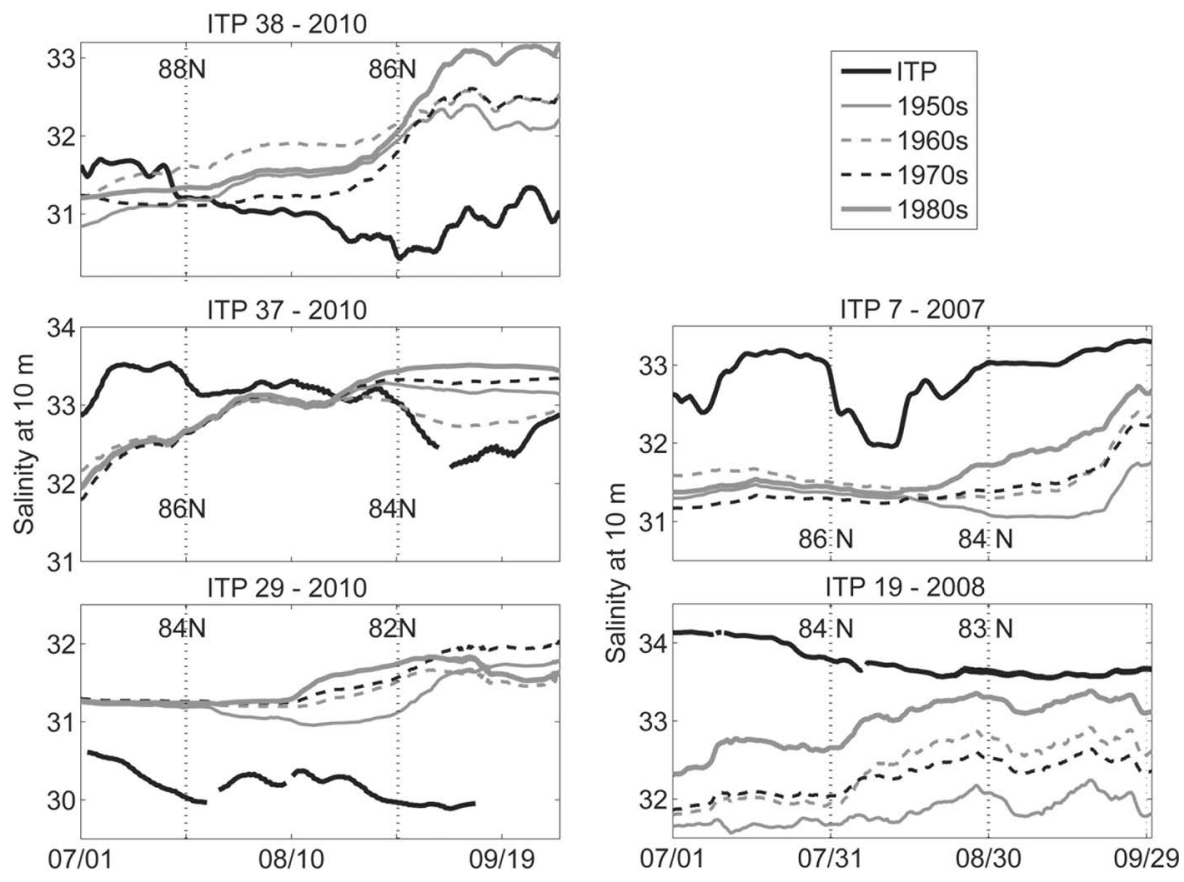

Figure 7. Salinity at $10 \mathrm{~m}$ from ITPs and Environmental Working Group climatological $10 \mathrm{~m}$ salinity (July, August, September) linearly interpolated to the ITP profile locations between 1 July and 30 September. Approximate latitudes are also shown for given times. Gaps in the ITP time series indicate times when the ITP did not return measurements from $10 \mathrm{~m}$, although position information was returned.

the halocline structure between 2007-2008 and 2010 (Figure 8). In 2007-2008, a seasonal halocline is present in the western Eurasian Basin between a surface mixed layer overlying a deeper winter mixed layer, while the halocline was stronger and sub-mixed-layer waters were fresher in 2010 (see Steele and Boyd [1998] for a full discussion of halocline formation mechanisms). Similar features are seen in May profiles in the Switchyard region, which also show an upper-ocean freshening between 2008 and 2010, with 2009 profiles (not shown) very similar to 2010 (Figure 9). The hydrographic change in the Switchyard region mirrors that observed by Alkire et al. [2007] between 2000 and 2003-2004. Alkire et al. [2007] showed 2000 conditions were fresh (as for 2009-2010), with a transition in 2003-2004 to saltier, deeper mixed layers (as for 2008-2007). The structure observed in 2000 and 2009-2010 can be associated with water originating on the Canadian side of the Lomonosov Ridge [e.g., McLaughlin et al., 2004; see also Jones et al., 1998]. As will be discussed in section 4, the hydrographic properties in the Switchyard region are highly variable, influenced by water that originates in different locations depending on the large-scale wind forcing [Steele et al., 2004].

[20] We hypothesize that the anomalously fresh surface water in the Eurasian Basin in 2010 was related to the recent reduction in strength of the Arctic high anticyclonic atmospheric forcing over the Beaufort Gyre [Proshutinsky et al., 2010]. It is possible that fresh water (e.g., river input at the boundaries) that would otherwise have been corralled in the Beaufort Gyre under strong anticyclonic forcing was able to penetrate the Eurasian Basin, or that fresh water escaped the Beaufort Gyre region under weaker convergent forcing (or divergent forcing), or a combination of these factors. These scenarios are tested in the next section using an idealized ice-ocean model forced by observed winds.

\section{Two-Dimensional Ice-Ocean Model Results}

\subsection{Model Configuration}

[21] A two-dimensional vertically integrated coupled iceocean barotropic model of the Arctic Ocean (developed by Proshutinsky [1993]) is used to investigate freshwater circulation and distribution. The $0.5^{\circ} \times 0.5^{\circ}$ resolution model does not include thermodynamics and employs a fixed sea ice thickness corresponding to mean climatic conditions [Proshutinsky and Johnson, 1997]. Sea ice follows the constitutive relationship outlined by Rothrock [1975], and ice concentration is prescribed monthly from observations. Wind stress forcing is derived from the 6-hourly National Center for Atmospheric Research-National Centers for Environmental Prediction (NCAR-NCEP) reanalysis product with a grid resolution of $2.5^{\circ} \times 2.5^{\circ}$. Real ocean depths are specified throughout the domain (as in Kowalik and Proshutinsky [1994]). Water transport is prescribed for major rivers draining into the Arctic Ocean. Monthly discharge data from 9 main rivers are obtained from the Regional, Hydrometeorological Data Network for the Pan-Arctic Region (http://www.r-arcticnet. sr.unh.edu/v4.0/) with recent updates from I. Shiklomanov (personal communication, 2010). At the North Pacific open boundary, a sea level anomaly of $+1.0 \mathrm{~m}$ is prescribed, whereas a radiation condition is applied at the open boundaries of the North Atlantic. These conditions establish a mean inflow from the Bering Sea into the Arctic Ocean of about 

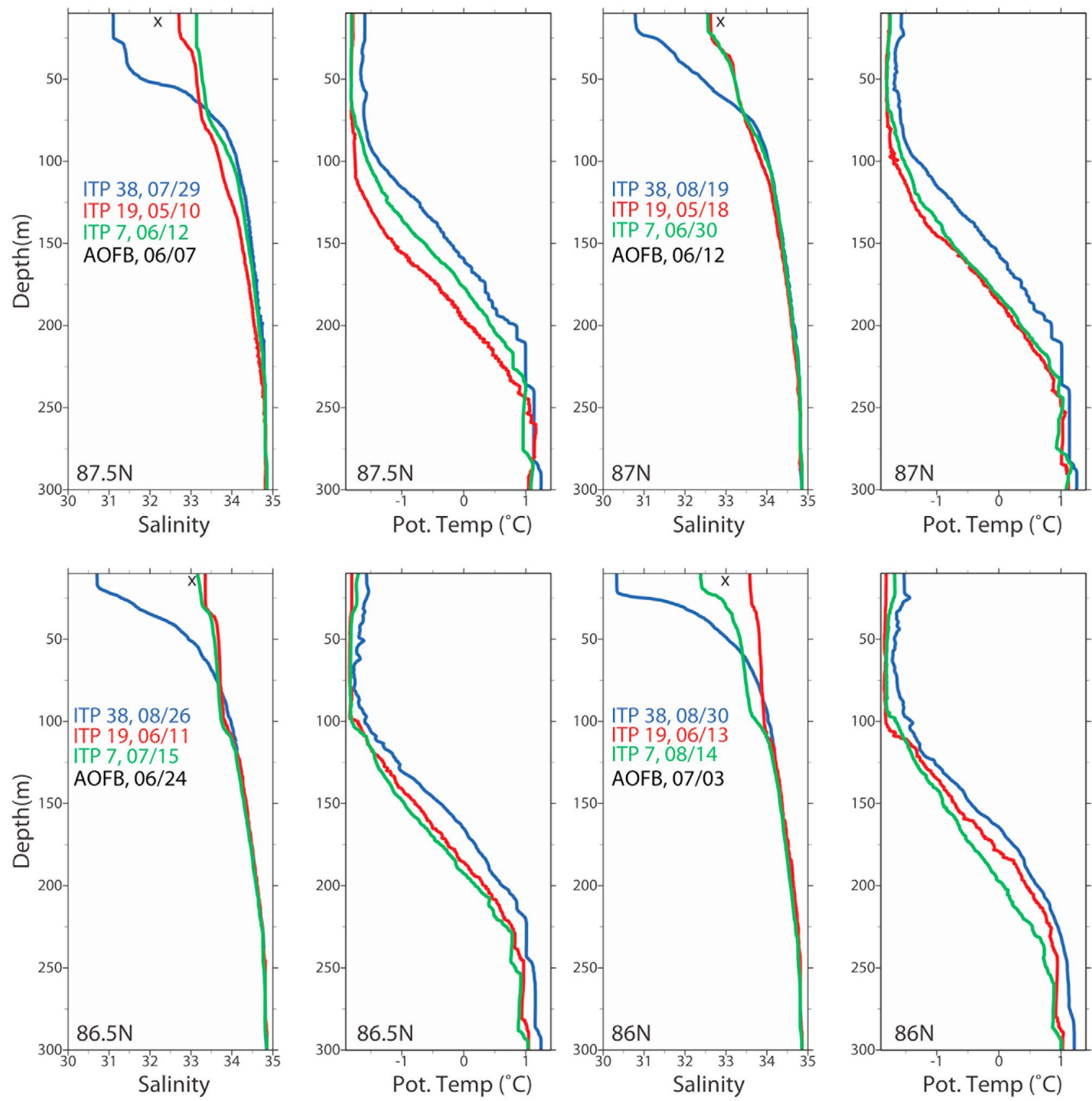

Figure 8. Salinity and potential temperature $\left({ }^{\circ} \mathrm{C}\right)$ profiles from ITP 7 (2007), ITP 19 (2008), and ITP 38 (2010) at four different latitudes near the prime meridian. Crosses in the salinity panels show mixed-layer salinity in 2009 measured by the AOFB. Note the important seasonal differences when each instrument was at a certain latitude.

$1 \mathrm{~Sv}$, which varies with wind forcing (further details are given by Proshutinsky and Johnson [1997]). Extensive model testing and validation against observed sea level time series along the Siberian coast and sea ice drift data from the International Arctic Buoy program (IABP; http://iabp.apl. washington.edu/) was performed by Proshutinsky [1993] and Proshutinsky and Johnson [1997]. Comparisons between model ice drift and 1 day averaged buoy velocities for 39 ITPs drifting in different parts of the Arctic basin between 2004 and 2010 (see http://www.whoi.edu/itp) indicate generally good agreement (an example is shown in Figure 10). Average correlation coefficients between simulated and observed velocity components are 0.8 , with no significant regional or temporal differences within the Arctic basin. The poorest correlations (around 0.65) are calculated for the 6 ITPs that exited the Arctic basin through Fram Strait and to the boundaries of the model domain; in this case, drift velocities are highly correlated until the ITP exits the basin. Of course, 

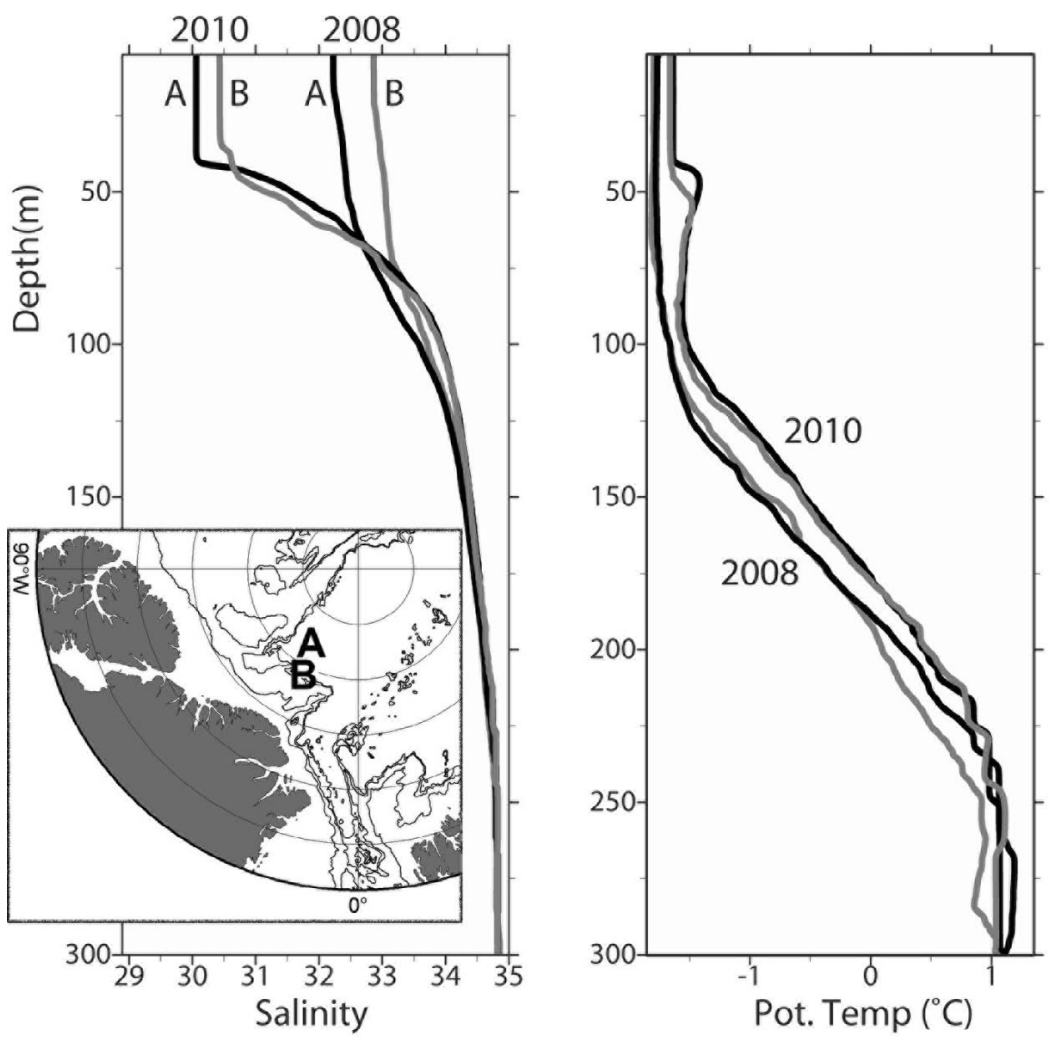

Figure 9. Salinity and potential temperature profiles from the Switchyard region (locations A and B) in May 2008 and May 2010.

some discrepancies are expected given, for example, imperfect model internal ice stresses and the coarse resolution reanalyzed wind fields.

[22] The model was run to simulate trajectories between 1990 and 2010 of conservative tracer particles that originated in the Beaufort Gyre region and from rivers along the Siberian coastline. Model spin up takes less than 2 months. Particles were released at 81 locations in a $9 \times 9$ grid centered over the Beaufort Gyre region with a grid spacing of $100 \mathrm{~km}$ and at 9 locations along the basin margins to track water originating from rivers. The coastal locations represent: the East Siberian Sea (Kolyma and Indigirka rivers), Laptev Sea (Khatanga, Olenek, Yana, and Lena rivers), and Kara Sea (Ob, Yenisei, and Pechora rivers). Every month, for the duration of each model run, a particle was released at each of the 81 or 9 sites. The particles are passive tracers advected by the ice or by surface water. For a more realistic estimate of parcel trajectories in the upper $10 \mathrm{~m}$ of the ocean, we applied a $20^{\circ}$ adjustment to the ice trajectories [see, e.g., McPhee, 1979] to account for the expected Ekman turning (most measurements under sea ice show a fairly well-developed Ekman spiral [see also McPhee, 2008]), and took as the ocean speed at $10 \mathrm{~m}$ the local ice velocity scaled by 0.7 . [cf. McPhee, 1979]. Of course this modeling exercise is only meant to provide approximate bounds on the wind-driven surface ocean circulation; the actual flow in the upper $10 \mathrm{~m}$ will depend on the exact characteristics of the ice-ocean boundary layer that varies with under-ice roughness, ice speed and buoyancy forcing.

\subsection{Surface Circulation}

[23] Sea level pressure and modeled annual sea ice motion demonstrate the strong interannual variability of the largescale circulation, changing conditions which impact upperocean circulation and freshwater content (Figure 11). The Beaufort Gyre was significantly reduced in strength in 2009 and 2010 compared to 2007 and 2008 (Figure 11). Further, the Transpolar Drift Stream was much weaker in the more recent 2 years, effectively absent in 2009. The years 2009 and 2010 exhibit a northward surface flow from the Beaufort Gyre region off the coast of Ellesmere Island (joining the flow off the coast of Greenland toward Fram Strait) that is not observed in 2007 and 2008.

[24] Ice and water pathways were assessed by examining the duration of time (particle hours) that particles occupied a given model grid cell. We consider 4 year periods to allow time for basin-scale transit from the Beaufort Gyre and shelf regions. Particles released to simulate ice (Figure 12) and surface water (Figure 13) in the Beaufort Gyre show that the years 2004-2008 were distinguished by a strong, anticyclonic Beaufort Gyre and an accumulation of fresh surface water here by converging Ekman transport, with no surfaceocean flow exiting the region. Model results corroborate observations of the major increase in Beaufort Gyre fresh water observed in these years [Proshutinsky et al., 2009; McPhee et al., 2009] and support the findings that the increase was caused by the dominant large-scale wind forcing. In 2009, the Beaufort Gyre weakened and ice and surface water are observed to escape the Beaufort Gyre in 

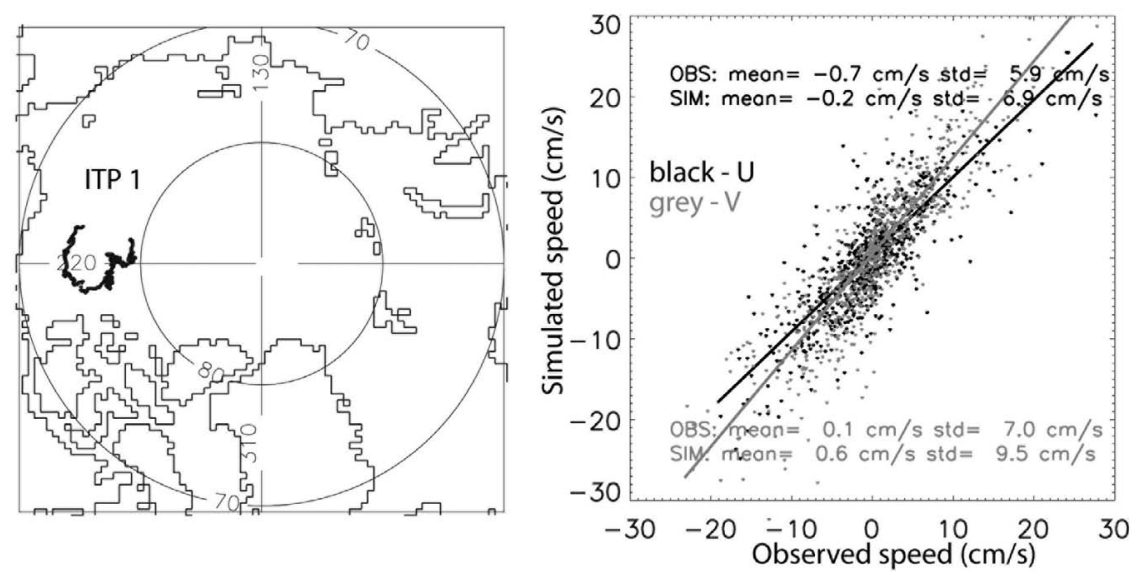

U component of ice drift

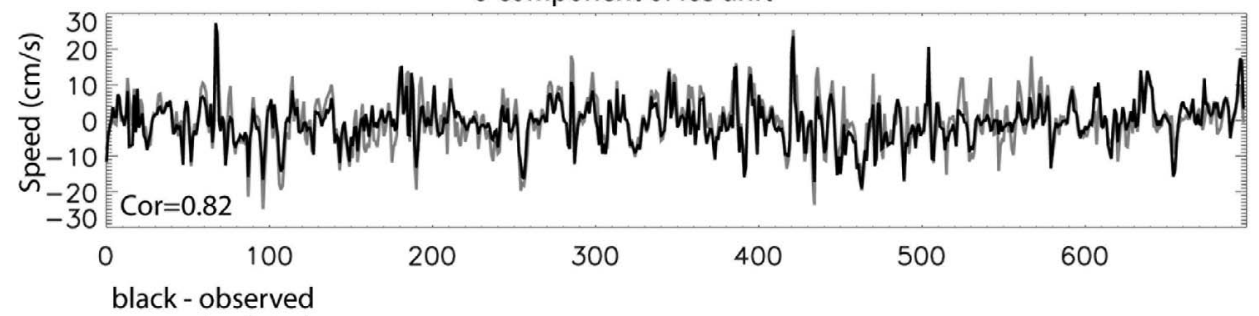

V component of ice drift

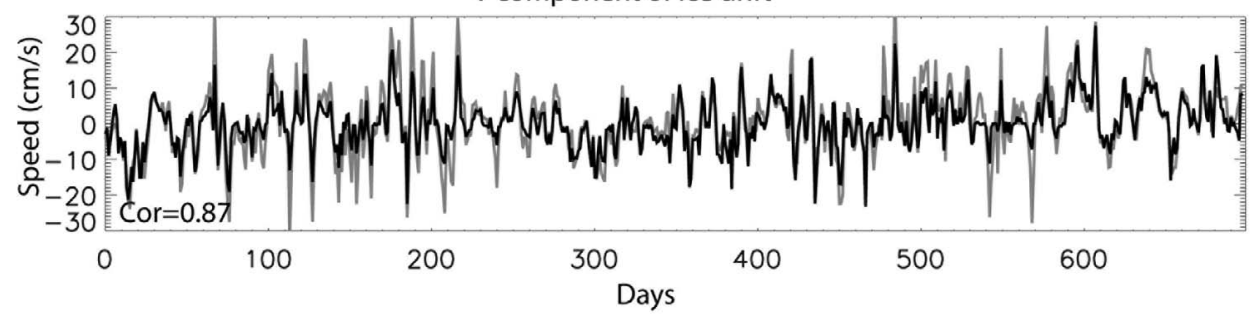

Figure 10. Comparison of simulated and observed ice drift for ITP 1, which drifted in the Beaufort Gyre for a total of 723 days between August 2005 and August 2007. Correlation coefficients were 0.82 for the $U$ (model coordinate $x$ direction) component of drift and 0.87 for the $V$ ( $y$ direction) component of drift.

the northern sector of the Canadian Basin, and spread toward the Switchyard region. While the surface ocean exhibits a similar qualitative response as the sea ice to altered atmospheric forcing starting around 2009, surface ocean particles are not observed to cross the $45^{\circ} \mathrm{W}$ line between Greenland and the North Pole. Note that this should only be considered a qualitative picture of the surface ocean circulation, given the uncertainties in estimating surface water flow by applying a magnitude and direction correction to sea ice motion (described in section 3.1). Taken together with observations, the model results imply that the freshwater distribution in 2010 is a manifestation of the weakening of the intense anticyclonic Beaufort Gyre circulation that persisted until 2008. The Beaufort Gyre strengthened somewhat in 2010 relative to 2009 (although remained generally weaker than in 2007 and 2008) which raises the question of whether the observed freshening is a short-term event. It may be that the slight increase in salinity in the Switchyard region between 2009 and 2010 signals a return to anticyclonic conditions associated with a Beaufort Gyre that corrals and retains fresh water.
[25] Particles released to simulate river discharge also show a response to the shift in large-scale atmospheric forcing (Figure 14). Until 2007, surface water originating along the Siberian coast was largely swept into, and confined to the Beaufort Gyre (in agreement with findings of Abrahamsen et al. [2009] and Dmitrenko et al. [2010]). This is consistent with analysis of dissolved barium (and other geochemical tracer) measurements in the Canada Basin mixed layer (in 2003-2004), that concluded that Eurasian river runoff dominates the fraction of meteoric water contained in the surface layer there [Guay et al., 2009]. Beginning in 2008, particles released along the coastline of the Kara Sea appear to transit with the Transpolar Drift Stream, leaving the Arctic via Fram Strait. Note that many particles originating from Siberian rivers remain for long times in the marginal seas propagating eastward with coastal currents because the wind-driven circulation was relatively weak.

[26] When model results are assessed in context with observations, the influence of direct river transport on surface fresh water in the Eurasian Basin is not clear. Recall ITP 37 operating further east of the IBO in 2010 recorded no 


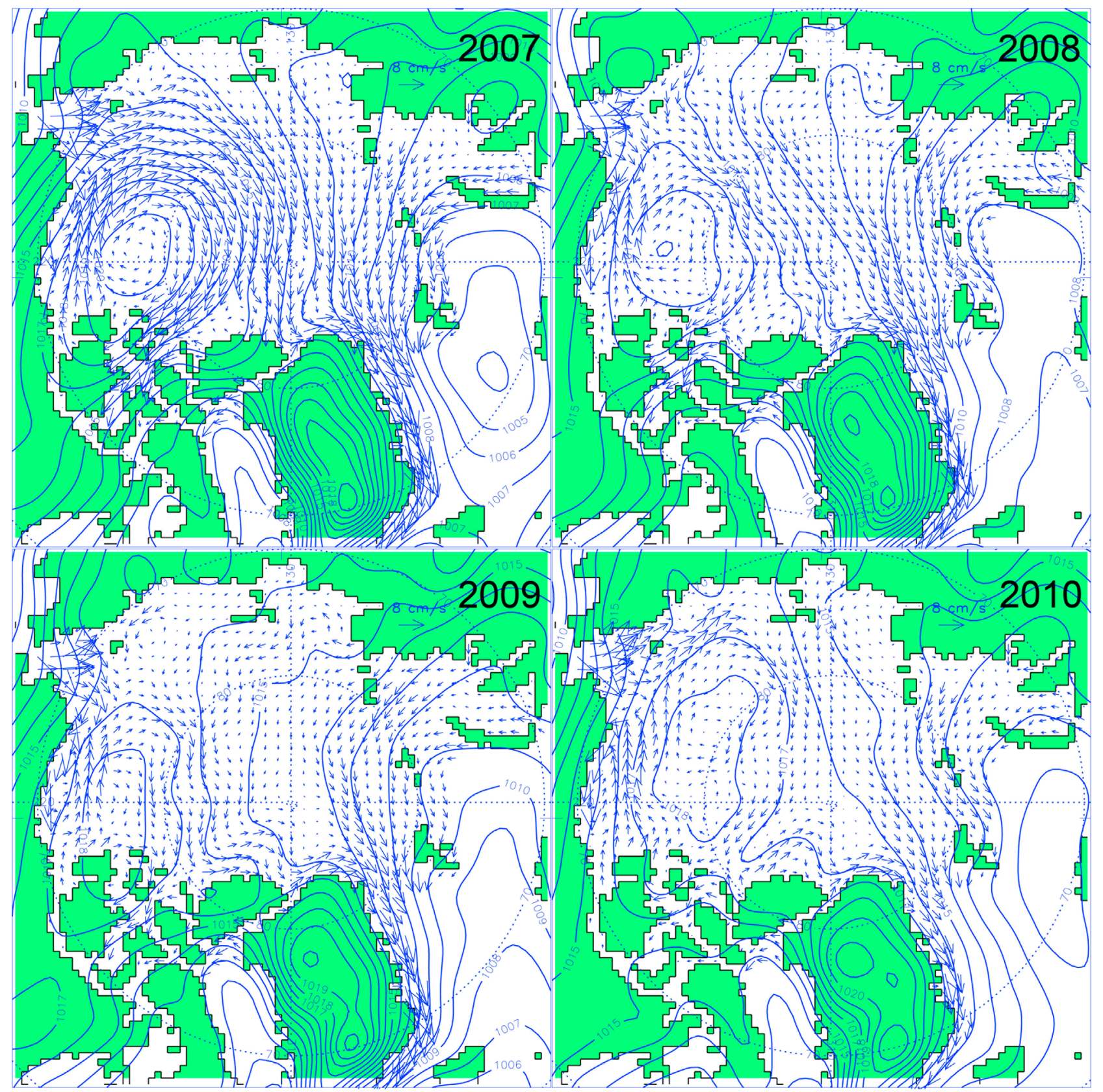

Figure 11. Map of model domain showing annually averaged ice drift (arrows) and sea level pressure (contours, hPa) for 2007, 2008, 2009, and 2010.

significant freshening (relative to climatology). Examination of April 2010 NPEO CTD profiles south from the North Pole along $90^{\circ} \mathrm{E}$ together with ITP 37 profiles (ITP 37 crossed $90^{\circ} \mathrm{E}$ in early May 2010) indicates a surface front (between 87 and $88^{\circ} \mathrm{N}$ ) between saltier mixed layers to the south and fresher mixed layers to the north. This structure suggests that the freshening measured by the 2010 IBO may not result from a change in the location where fresh shelf waters are fluxed out into the Eurasian Basin (at least not from the Kara Sea since we would expect a freshwater signal from the Kara Sea to show up in the drift region of ITP 37). Rather, the expansion and release of fresh water from the Beaufort Gyre might dominate the anomalous freshwater signal observed along the prime meridian. The influence of direct freshwater fluxes from the Laptev and East Siberian seas remains a possibility as it is conceivable that these waters could transit on the fresh (northern) side of the surface front mentioned above.

\section{Discussion and Summary}

[27] We have analyzed IBO measurements to show that the upper-ocean salinity in the region between the North Pole and Fram Strait is observed to be appreciably fresher there in summer 2010 compared to years 2007 and 2008. Comparable melt in all 3 years suggests that the observed freshening is not related to enhanced seasonal melt. This surface freshening is 

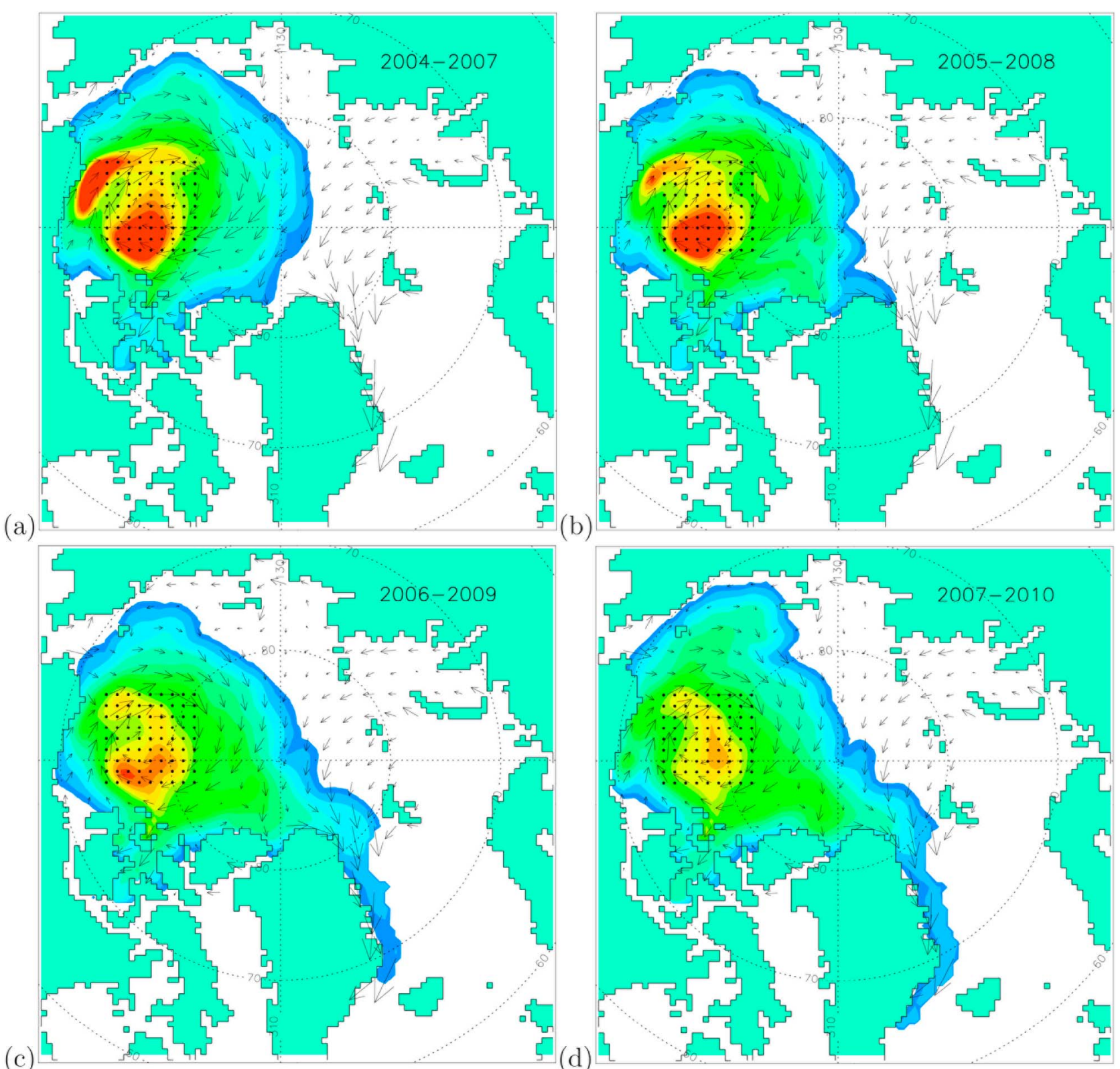

(b)

(c)

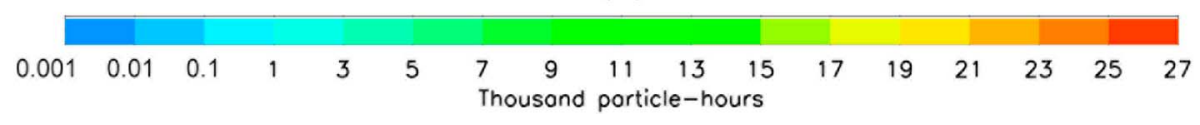

Figure 12. Map of model domain showing colored contours of ice tracer "particle hours" (see text) for (a) 2007, (b) 2008, (c) 2009, and (d) 2010. Each map includes only particles released in the Beaufort Gyre in the 4 years labeled in the top corner. The model run was initiated in 1990. Arrows show ice circulation averaged over the 4 year periods, and dots in the Beaufort Gyre indicate particle release locations.

also seen in hydrographic measurements in the Switchyard region between Ellesmere Island-northern coast of Greenland and the North Pole.

[28] The most likely cause of the freshening appears to be a redistribution of fresh water within the Arctic Ocean forced by changes in the prevailing wind field that allowed fresh surface water to escape the Beaufort Gyre and penetrate the Eurasian Basin. Two-dimensional ice-ocean model results provide evidence to strengthen this hypothesis, demonstrat- ing the weakening of the Beaufort Gyre circulation and release to the north of stored fresh water. Note that isopycnal displacements in the Beaufort Gyre appear to respond relatively rapidly to changes in wind-stress curl (a downward doming during strong anticyclonic wind forcing, and a relaxation when the forcing weakens, typically in summer). This is shown by the correlation between Beaufort Gyre freshwater content and wind-stress curl on seasonal time scales, taking into account freshwater changes due to the 

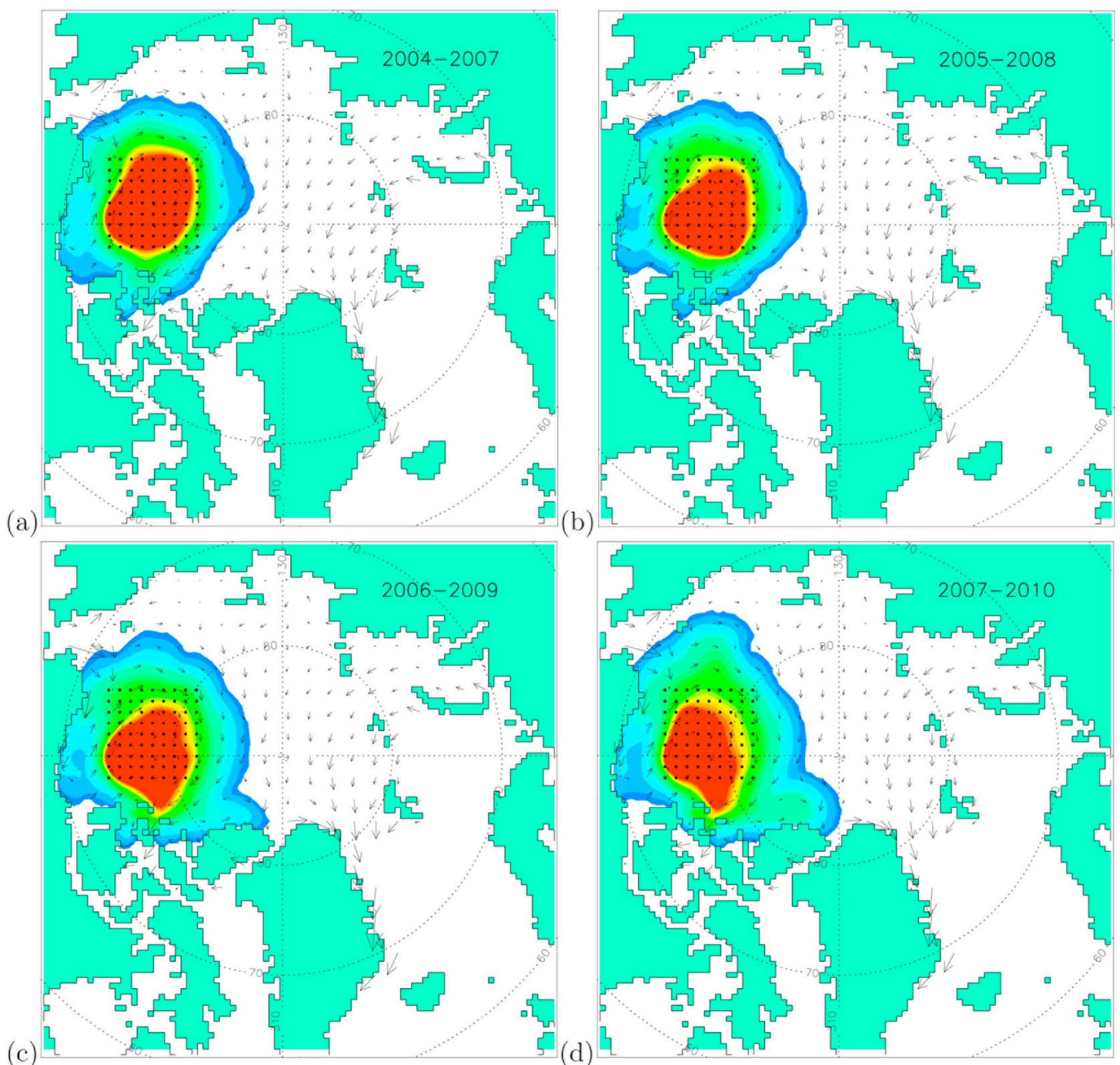

(b)

(c)
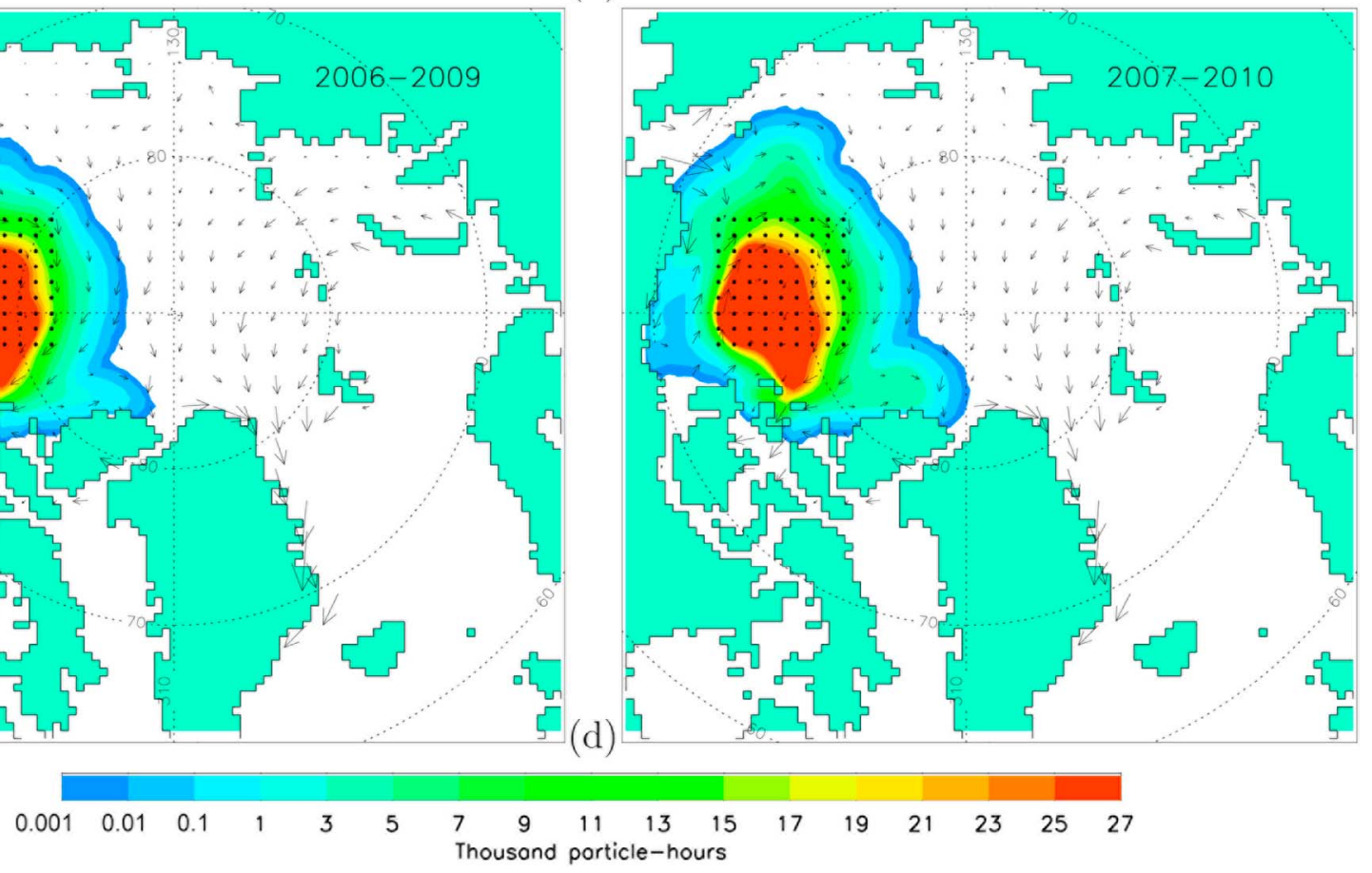

Figure 13. Same as Figure 12 but for water tracer "particle hours." Arrows show water circulation at $10 \mathrm{~m}$ depth averaged over the 4 year periods.

growth and melt of sea ice [Proshutinsky et al., 2009]. This suggests that the entire surface-ocean gyre circulation likely responds rapidly to changes in the large-scale wind forcing.

[29] Steele and Boyd [1998] observed that a reverse (possibly related) shift took place between the 1980s and 1991-1995; they described a salinification of the surface waters in the Eurasian Basin, and a much reduced salinity gradient between 60 and $90 \mathrm{~m}$ depth. Steele and Boyd [1998] refer to this as the retreat of the cold halocline in the early 1990s, with fresher surface waters retreating from the Amundsen Basin into the Makarov Basin. They showed how this was likely related to a change in large-scale wind- driven circulation, manifested as a shift in the axis of the Transpolar Drift Stream from the Eurasian sector to the Canadian sector in the early 1990s relative to the 1980s. They speculated that the salinification results from less influence of fresh shelf water from the Kara and Laptev seas in the 1990s [see also Dmitrenko et al., 2008]. This water was carried eastward in the 1990s instead of being transported directly out into the Eurasian Basin in the Transpolar Drift Stream as it was in the 1980s. In this way, changes in the wind forcing resulted in a retreat of fresh surface waters from the Amundsen Basin into the Makarov Basin. A partial return of this cold halocline layer was seen in the late 1990s, 

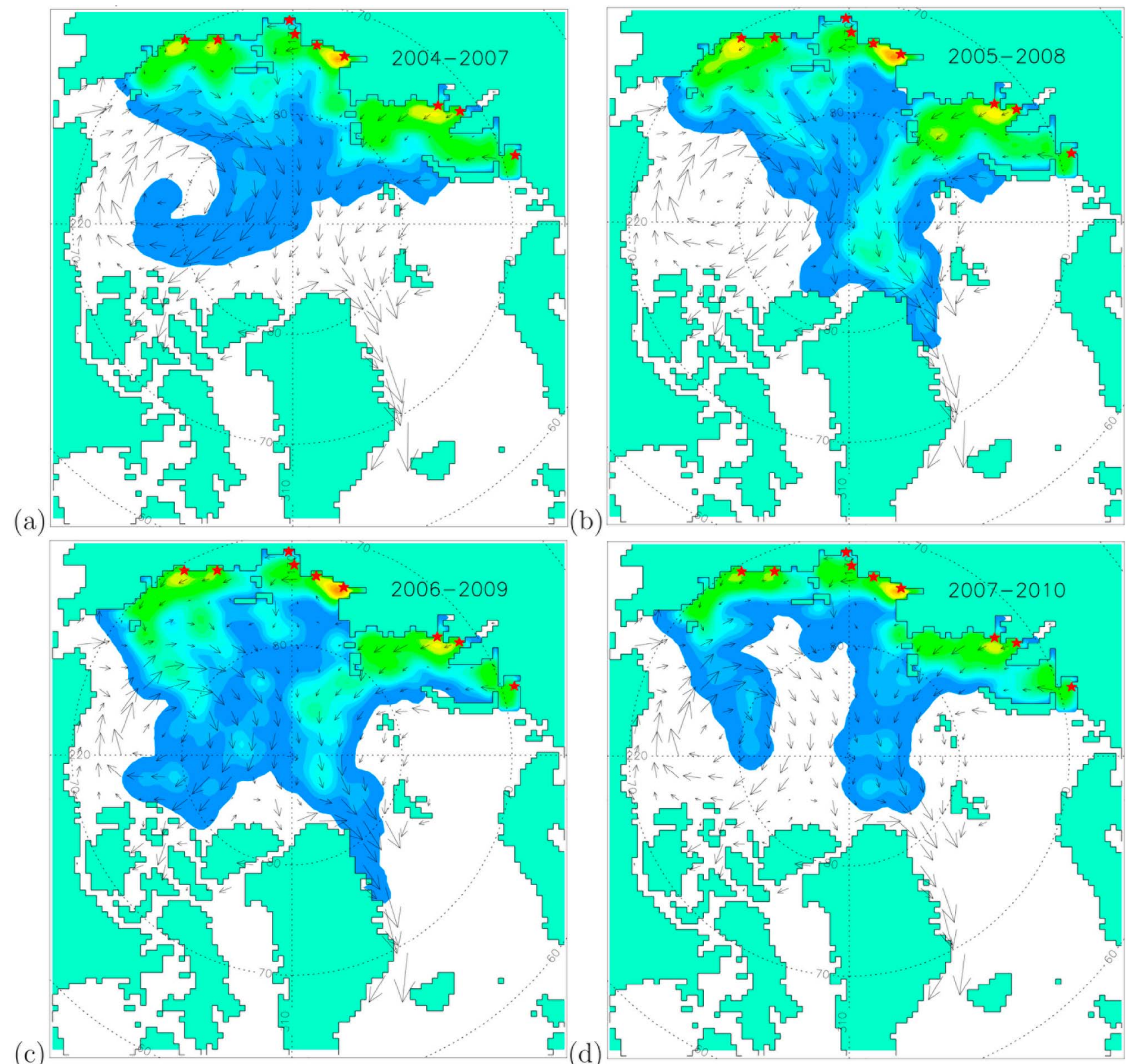

(b)

(c)
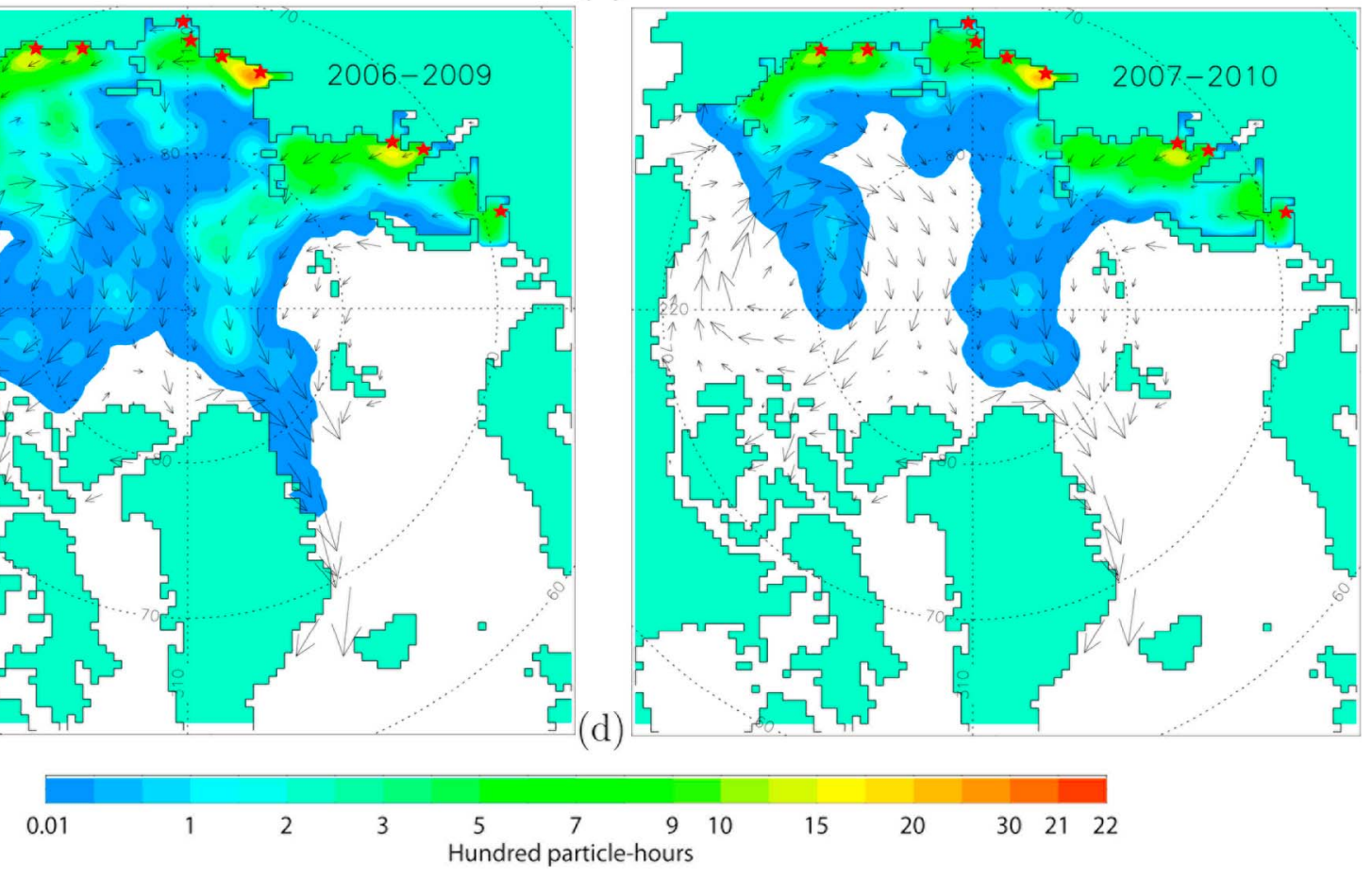

Figure 14. Same as Figure 13 but for particles released at Siberian river mouths. Red stars indicate particle release locations.

evidently a result of the reestablishment of direct transport into the eastern Eurasian Basin of fresh shelf waters from the Kara and Laptev seas [Boyd et al., 2002]. In the early 1990s the weak Arctic high (cyclonic conditions) shifted the Transpolar Drift Stream toward the Alpha-Mendeleyev Ridge causing ice and surface water to flow east from the Laptev and East Siberian seas toward Bering Strait. In the late 1990s, there was a strong Arctic high (anticyclonic conditions) and the Transpolar Drift Stream shifted back to the Lomonosov Ridge again. On the other hand, in 20092010 a freshening of the western Eurasian Basin (possibly associated with a return of the cold halocline compared to
2007-2008 conditions) was observed in the presence of a weak Arctic high. In these recent years, the role of fresh water from the shelf regions (at least from the Kara Sea) is less clear since an ITP in the direct pathway of Kara Seawater shows no anomalous freshening. Fresh water arriving directly from the Laptev and East Siberian seas may, however, play an important role.

[30] It remains a possibility that enhanced river runoff in the 2000s [Shiklomanov and Lammers, 2009] intensified the freshwater anomaly in the Eurasian Basin (over what would have been observed given more typical river discharge in the years preceding the change in atmospheric circulation); this 
is very difficult to evaluate given that locally, the wind-driven variability in freshwater content can be 20 to 30 times larger than the river discharge anomaly [Dmitrenko et al., 2008]. The very fresh conditions in the Beaufort Gyre prior to 2009 may have also influenced the freshwater anomaly. Upper-ocean salinity information is not sufficient to constrain the variability due to different fresh water sources. In addition, the mixed layer is modified during transit by surface fluxes, convection and shear-driven mixing. Analysis of conservative geochemical tracers [cf. Macdonald et al., 2002; Anderson et al., 2004; Guay et al., 2009] is required to determine the composition and place bounds on the evolution of fresh water from the basin boundaries and Beaufort Gyre to the Eurasian Basin and Fram Strait.

[31] The results shown here reinforce past studies attesting to the significant, apparently rapid, changes in upper-ocean properties in this part of the Arctic. Alkire et al. [2007], for example, showed how the upper ocean in the region between the Switchyard and the North Pole is marked by substantial interannual variability. They analyzed temperature, salinity and chemical measurements to show how the Pacific Water contribution to the mixed layer in this region varies significantly on interannual time scales, with no clear link between this variability and the large-scale atmospheric indices. Alkire et al. [2007] further showed that the circulation of the mixed layer and deeper halocline layers can be decoupled suggesting they respond on different time scales to large-scale atmospheric forcing. While the ice and mixed layer evidently respond rapidly to changes in the wind field, the deeper layers could take many months or years to respond. This was inferred by Morison et al. [2006] who showed hydrographic changes (particulary in the Atlantic Water) in the central Arctic between 2000 and 2005 lagged shifts in the large-scale wind-driven circulation by a few years.

[32] We cannot speculate whether the changed surface freshwater state is a short-term phenomenon or whether this freshwater configuration signals a longer-term change, perhaps lasting years. It is apparent that the changed upper ocean is not a seasonal migration and has likely persisted at least over 2009 and 2010. Nevertheless, the rapid surface freshwater distribution change has marked effects on Arctic stratification and potentially on the export of fresh water from the Arctic, and demonstrates the importance of yearly IMB and ITP deployments in the region between the North Pole and Fram Strait.

[33] The extent to which the anomalously fresh surface waters observed along the prime meridian in 2010 and close to the north coast of Greenland in 2009 and 2010 contributed to enhanced freshwater fluxes at Fram Strait is not known. A decade-long record of mooring measurements in Fram Strait show no significant change in ocean freshwater flux through the strait between 1998 and 2008 [de Steur et al., 2009]. This is consistent with the large-scale anticyclonic circulation over this period. Recent measurements will no doubt show an increase in the freshwater flux. Challenges for future studies will be in observational and modeling efforts to understand the duration and defined source of these freshwater changes and redistributions, and in predicting how a changed surface freshwater distribution in the Arctic will impact North Atlantic and global climate.
[34] Acknowledgments. The instruments used in this study were deployed in collaboration with the North Pole Environmental Observatory (NPEO) from the Russian Barneo ice camps with logistic support provided by Andy Heiberg from the Polar Science Center (University of Washington) and Tom Quinn from CH2M Hill Polar Services. We appreciate the use of CTD data from the Freshwater Switchyard of the Arctic Ocean and the NPEO hydrographic surveys. The Ice-Tethered Profiler data were collected and made available by the Ice-Tethered Profiler Program based at the Woods Hole Oceanographic Institution (http://www.whoi.edu/itp). This work was funded by the National Science Foundation Office of Polar Programs Arctic Sciences Section under awards ARC-0519899, ARC-0856479, and ARC0806306. Web cam images were provided by NOAA-PMEL. Ocean Data View software was used in this work (http://odv.awi.de/).

\section{References}

Aagaard, K., and E. C. Carmack (1989), The role of sea ice and other fresh water in the Arctic Circulation, J. Geophys. Res., 94, 14,485-14,498, doi:10.1029/JC094iC10p14485

Abrahamsen, E. P., M. P. Meredith, K. K. Falkner, S. Torres-Valdes, M. J. Leng, M. B. Alkire, S. Bacon, S. W. Laxon, I. Polyakov, and V. Ivanov (2009), Tracer-derived freshwater composition of the Siberian continental shelf and slope following the extreme Arctic summer of 2007, Geophys. Res. Lett., 36, L07602, doi:10.1029/2009GL037341.

Alkire, M. B., K. K. Falkner, I. Rigor, M. Steele, and J. Morison (2007), The return of Pacific waters to the upper layers of the central Arctic Ocean, Deep Sea Res. Part I, 54, 1509-1529.

Anderson, L. G., S. Jutterström, S. Kaltin, E. P. Jones, and G. Björk (2004) Variability in river runoff distribution in the Eurasian Basin of the Arctic Ocean, J. Geophys. Res., 109, C01016, doi:10.1029/2003JC001773.

Boyd, T. J., M. Steele, R. D. Muench, and J. T. Gunn (2002), Partial recovery of the Arctic Ocean halocline, Geophys. Res. Lett., 29(14), 1657, doi:10.1029/2001GL014047.

Déry, S. J., and M. K. Yau (2002), Large-scale mass balance effects of blowing snow and surface sublimation, J. Geophys. Res., 107(D23), 4679, doi:10.1029/2001JD001251.

de Steur, L., E. Hansen, R. Gerdes, M. Karcher, E. Fahrbach, and J. Holfort (2009), Freshwater fluxes in the East Greenland Current: A decade of observations, Geophys. Res. Lett., 36, L23611, doi:10.1029/2009GL041278.

Dmitrenko, I. A., S. A. Kirillov, and L. B. Tremblay (2008), The long-term and interannual variability of summer fresh water storage over the eastern Siberian shelf: Implication for climatic change, J. Geophys. Res., 113, C03007, doi:10.1029/2007JC004304.

Dmitrenko, I. A., S. A. Kirillov, T. Krumpen, M. Makhotin, E. P. Abrahamsen, S. Willmes, E. Bloshkina, J. A. Holemann, H. Kassens, and C. Wegner (2010), Wind-driven diversion of summer river runoff preconditions the Laptev Sea coastal polynya hydrography:Evidence from summer-to-winter hydrographic records of 2007-2009, Cont. Shelf Res., 30, 1656-1664, doi:10.1016/j.csr.2010.06.012

Guay, C. K. H., F. A. McLaughlin, and M. Yamamoto-Kawai (2009), Differentiating fluvial components of upper Canada Basin waters on the basis of measurements of dissolved barium combined with other physical and chemical tracers, J. Geophys. Res., 114, C00A09, doi:10.1029/2008JC005099.

Hunkins, K., and J. A. Whitehead (1992), Laboratory simulation of exchange through Fram Strait, J. Geophys. Res., 97, 11,299-11,322, doi:10.1029/ 92JC00735.

Johnson, G. C., J. M. Toole, and N. G. Larson (2007), Sensor corrections for Sea-Bird SBE-41CP and SBE-41 CTDs, J. Atmos. Oceanic Technol., 24, $1117-1130$

Jones, E. P., L. G. Anderson, and J. H. Swift (1998), Distribution of Atlantic and Pacific waters in the upper Arctic Ocean: Implications for circulation, Geophys. Res. Lett., 25, 765-768, doi:10.1029/98GL00464.

Kowalik, Z., and A. Y. Proshutinsky (1994), The Arctic Ocean tides, in The Polar Oceans and Their Role in Shaping the Global Environment, Geophys. Monogr. Ser., vol. 85, edited by O. Johannessen, R. D. Muench, and J. E. Overland, pp. 137-158, AGU, Washington, D. C.

Krishfield, R. A., and D. K. Perovich (2005), Spatial and temporal variability of oceanic heat flux to the Arctic ice pack, J. Geophys. Res., 110, C07021, doi:10.1029/2004JC002293.

Krishfield, R., J. Toole, A. Proshutinsky, and M.-L. Timmermans (2008), Automated ice-tethered profilers for seawater observations under pack ice in all seasons, J. Atmos. Oceanic Technol., 47, 2091-2105.

Macdonald, R. W., F. A. McLaughlin, and E. C. Carmack (2002), Fresh water and its sources during the SHEBA drift in the Canada Basin of the Arctic Ocean, Deep Sea Res. Part I, 49, 1769-1785.

McLaughlin, F. A., E. C. Carmack, R. W. Macdonald, H. Melling, J. H Swift, P. A. Wheeler, B. F. Sherr, and E. B. Sherr (2004), The joint roles 
of Pacific and Atlantic-origin waters in the Canada Basin, 1997-1998, Deep Sea Res. Part I, 51, 107-128.

McPhee, M. G. (1979), The effect of the oceanic boundary layer on the mean drift of pack ice: Application of a simple model, J. Phys. Oceanogr., 9, 388-400.

McPhee, M. G. (1992), Turbulent heat flux in the upper ocean under sea ice, J. Geophys. Res., 97, 5365-5379, doi:10.1029/92JC00239.

McPhee, M. G. (2008), Air-Ice-Ocean Interaction: Turbulent Ocean Boundary Layer Exchange Processes, Springer, New York.

McPhee, M. G., T. Kikuchi, J. H. Morison, and T. P. Stanton (2003), Ocean-to-ice heat flux at the North Pole environmental observatory, Geophys. Res. Lett., 30(24), 2274, doi:10.1029/2003GL018580.

McPhee, M. G., A. Proshutinsky, J. H. Morison, M. Steele, and M. B. Alkire (2009), Rapid change in freshwater content of the Arctic Ocean, Geophys. Res. Lett., 36, L10602, doi:10.1029/2009GL037525.

Morison, J., M. Steele, and R. Andersen (1998), Hydrography of the upper Arctic Ocean measured from the nuclear submarine U.S.S. Pargo, Deep Sea Res. Part I, 45, 15-38.

Morison, J., M. Steele, T. Kikuchi, K. Falkner, and W. Smethie (2006), Relaxation of central Arctic Ocean hydrography to pre-1990s climatology, Geophys. Res. Lett., 33, L17604, doi:10.1029/2006GL026826.

Newton, R., P. Schlosser, D. G. Martinson, and W. Maslowski (2008), Freshwater distribution in the Arctic Ocean: Simulation with a highresolution model and model-data comparison, J. Geophys. Res., 113, C05024, doi:10.1029/2007JC004111.

Nicolaus, M., S. Gerland, S. R. Hudson, S. Hanson, J. Haapala, and D. K. Perovich (2010), Seasonality of spectral albedo and transmittance as observed in the Arctic Transpolar Drift in 2007, J. Geophys. Res., 115, C11011, doi:10.1029/2009JC006074.

Peterson, B. J., R. M. Holmes, J. W. McClelland, C. J. Vorosmarty, R. B. Lammers, A. I. Shiklomanov, I. A. Shiklomanov, and S. Rahmstorf (2002), Increasing river discharge to the Arctic Ocean, Science, 298, 2171-2173.

Polyakov, I. V., V. Alexeev, G. I. Belchansky, I. A. Dmitrenko, V. Ivanov, S. Kirillov, A. Korablev, M. Steele, L. A. Timokhov, and I. Yashayaey (2008), Arctic Ocean freshwater changes over the past 100 years and their causes, J. Clim., 21, 364-384.

Proshutinsky, A. Y. (1993), Arctic Ocean Level Oscillations (in Russian), Gidrometeoizdat, St. Petersburg, Russia.

Proshutinsky, A. Y., and M. A. Johnson (1997), Two circulation regimes of the wind-driven Arctic Ocean, J. Geophys. Res., 102, 12,493-12,514 doi:10.1029/97JC00738.

Proshutinsky, A., and M. Johnson (2010), Decadal variability of Arctic climate: Cyclonic and anticyclonic circulation regimes, Abstract GC12B-09 presented at 2010 Fall Meeting, AGU, San Francisco, Calif., 13-17 Dec.

Proshutinsky, A., I. V. Polyakov, and M. Johnson (2000), Climate states and variability of Arctic ice and water dynamics during 1946-1997, Polar Res., 18, 135-142.

Proshutinsky, A., R. H. Bourke, and F. A. McLaughlin (2002), The role of the Beaufort Gyre in Arctic climate variability: Seasonal to decadal climate scales, Geophys. Res. Lett., 29(23), 2100, doi:10.1029/2002GL015847.
Proshutinsky, A., R. Krishfield, M.-L. Timmermans, J. Toole, E. Carmack, F. McLaughlin, W. J. Williams, S. Zimmermann, M. Itoh, and K. Shimada (2009), Beaufort Gyre freshwater reservoir: State and variability from observations, J. Geophys. Res., 114, C00A10, doi:10.1029/2008JC005104.

Proshutinsky, A., et al. (2010), Ocean, Bull. Am. Meteorol. Soc., 91, S109-S112.

Rabe, B., M. Karcher, U. Schauer, J. M. Toole, R. A. Krishfield, S. Pisarev, F. Kaukera, R. Gerdes, and T. Kikuchi (2010), An assessment of panArctic Ocean freshwater content changes from the 1990s to the IPY period, Deep Sea Res. Part I, 58, 173-185, doi:10.1016/j.dsr.2010.12.002.

Richter-Menge, J. A., et al. (2006), Ice mass balance buoys: A tool for measuring and attributing changes in the thickness of the Arctic sea ice cover, Ann. Glaciol., 44, 205-210.

Rothrock, D. A. (1975), The mechanical behavior of pack ice, Ann. Rev. Earth Planet. Sci., 3, 317-342.

Serreze, M., A. P. Barrett, A. G. Slater, R. A. Woodgate, K. Aagaard, R. B. Lammers, M. Steele, R. Moritz, M. Meredith, and C. M. Lee (2006), The large-scale freshwater cycle of the Arctic, J. Geophys. Res., 111, C11010, doi:10.1029/2005JC003424

Shaw, W. J., T. P. Stanton, M. G. McPhee, and T. Kikuchi (2008), Estimates of surface roughness length in heterogeneous under-ice boundary layers, J. Geophys. Res., 113, C08030, doi:10.1029/2007JC004550.

Shiklomanov, A. (2010), River discharge, Bull. Am. Meteorol. Soc., 91, S116-S117.

Shiklomanov, A., and R. Lammers (2009), Record Russian river discharge in 2007 and the limits of analysis, Environ. Res. Lett., 4, 045015, doi:10.1088/1748-9326/4/4/045015.

Steele, M., and T. Boyd (1998), Retreat of the cold halocline layer in the Arctic Ocean, J. Geophys. Res., 103, 10,419-10,435, doi:10.1029/98JC00580.

Steele, M., and W. Ermold (2004), Salinity trends on the Siberian shelves, Geophys. Res. Lett., 31, L24308, doi:10.1029/2004GL021302.

Steele, M., J. Morison, W. Ermold, I. Rigor, M. Ortmeyer, and K. Shimada (2004), Circulation of summer Pacific halocline water in the Arctic Ocean, J. Geophys. Res., 109, C02027, doi:10.1029/2003JC002009.

Toole, J. M., M.-L. Timmermans, D. K. Perovich, R. A. Krishfield, A. Proshutinsky, and J. A. Richter-Menge (2010), Influences of the ocean surface mixed layer and thermohaline stratification on Arctic Sea ice in the central Canada Basin, J. Geophys. Res., 115, C10018, doi:10.1029/ 2009JC005660.

Wettlaufer, J. S. (1991), Heat flux at the ice-ocean interface, J. Geophys. Res., 96, 7215-7236.

R. A. Krishfield, A. Proshutinsky, and J. M. Toole, Department of Physical Oceanography, Woods Hole Oceanographic Institution, 266 Woods Hole Rd., Woods Hole, MA 02543, USA.

D. K. Perovich and J. A. Richter-Menge, Cold Regions Research and Engineering Laboratory, 72 Lyme Rd., Hanover, NH 03755-1290, USA.

T. P. Stanton, Department of Oceanography, Naval Postgraduate School, 833 Dyer Rd., Monterey, CA 93943, USA.

M.-L. Timmermans, Department of Geology and Geophysics, Yale University, 210 Whitney Ave., New Haven, CT 06511, USA. (mary-louise. timmermans@yale.edu) 